\title{
Identifying the Conjunction of Exploration Factors in the Tafresh Area That Lead to Present Three Potential Areas for Au and Cu Deposits
}

\author{
Akram Shahhosseini' ${ }^{1}$, Leila Hosseina ${ }^{2}$ \\ ${ }^{1}$ Geomatics Dept, Geology survey of Iran, Tehran, Iran \\ ${ }^{2}$ Engineering Advisory Company, Foundation, Structures, Mining Company (PSM Co.), Shahrood, Iran \\ Email: akram.shahhosseini@gmail.com,leilahosseina@gmail.com
}

Received 12 April 2016; accepted 27 June 2016; published 30 June 2016

Copyright (C) 2016 by authors and Scientific Research Publishing Inc.

This work is licensed under the Creative Commons Attribution International License (CC BY).

http://creativecommons.org/licenses/by/4.0/

(c) (i) Open Access

\begin{abstract}
Our study area "Tafresh" is located in the sedimentary-volcanic belt. This work was carried out as systematic for surveying ore potentials at Tafresh base on the geology, geochemistry, laboratories studies, remote sensing, and tectonic. According to study of 109 samples, most of the area's mineralization has been associated with Dacite, Diorite, Tonalite intrusive massive, Andesitic dykes which are related to operation of thrust and strike slip faults. Also, most of these ore deposits had been concentrated at sedimentary rocks of Cretaceous that involves Limestone and Shale in the Southwest and Andesite to Andesitic Basalt at the Northern of Tafresh area. Most of the alterations zones associated with mineralization are androgenic like Argillic, Propylitic, Sericitic, and siliceous alterations that have appropriate adaptation with area's major faults as well. Eventually, based on the geochemical studies and incorporating all data by GIS software, Tafresh has remarkable concentration of $\mathrm{Cu}$ and $\mathrm{Au}$ ore deposits that are recognized as Skarn and Hydrothermal ore deposits which are related to fluids flowing from intrusive massive and dykes.
\end{abstract}

\section{Keywords}

Tafresh, Copper, Gold, Skarn, Hydrothermal, Androgenic

\section{Introduction}

Tafresh area situated at longitude coordinate $50^{\circ} 00^{\prime} 00^{\prime \prime}$ to $50^{\circ} 07^{\prime} 30^{\prime \prime}$ and latitude coordinate $34^{\circ} 37^{\prime} 30^{\prime \prime}$ to 
$34^{\circ} 45^{\prime} 00^{\prime \prime}$ at the eastern part of Markazi Province (Figure 1). Tafresh area is part of Central Iran zone and Sahand-Bazman's volcanic belt [1] and this area is part of Urumieh-Dokhtar belt as well [2]. The Urumieh-Dokhtar belt is related to subduction zone of Neotethys' oceanic plate that subsequently, Arabian plate went under Iran plate in the period of Middle Miocene, around the 13 Million years ago. Also, Tafresh area located between Index fault at the Northeast and Talkhab fault at the Southwest [3]. One of the significant characteristics of this area is volcanic deposits of Cenozoic, volcano sedimentary and sedimentary deposits that along with several numbers of semi-deep and deep intrusive massive of Tertiary [16]. The most of common procedure of tectonic structures is Northwest and Southeast (Figure 2). In the second degree, sedimentary rocks of Triassic, Jurassic, Cretaceous, and Quaternary are remarkable.

\section{Geology of Tafresh}

Sedimentary-Volcanic collection of Eocene is most widespread lithological unites of this area [4] [5]. This collection included various kinds of rocks such as; conglomerate, sandstone, marl, limestone along with tuff, lava, volcano sedimentary rocks, and ignimbrite as interlayer.

Lagoon and continental conditions with sediments of Red Formation, which are well-off as pristine series had been formed by some tectonic movements which belong to Late Eocene and Early Oligocene, and these motions are paralleled with Pirineh Phase. In the period of time of Late Oligocene-Early Miocene, the sea had been extended [6] and whereby some limeston and marly sediments of Qom Formation were formed. Also, in this

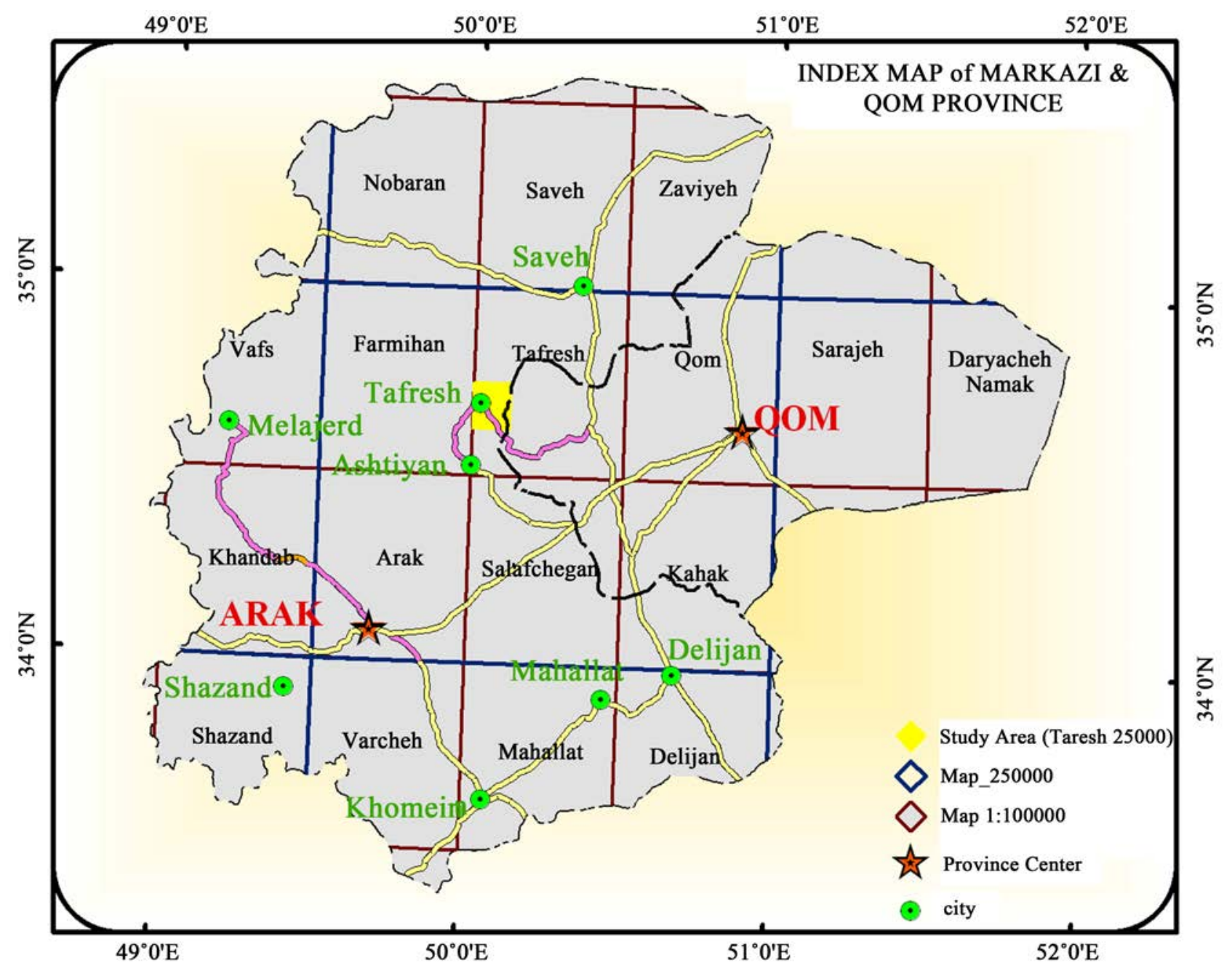

Figure 1. Location of Tafresh area in the Markazi province and accessible roads. 


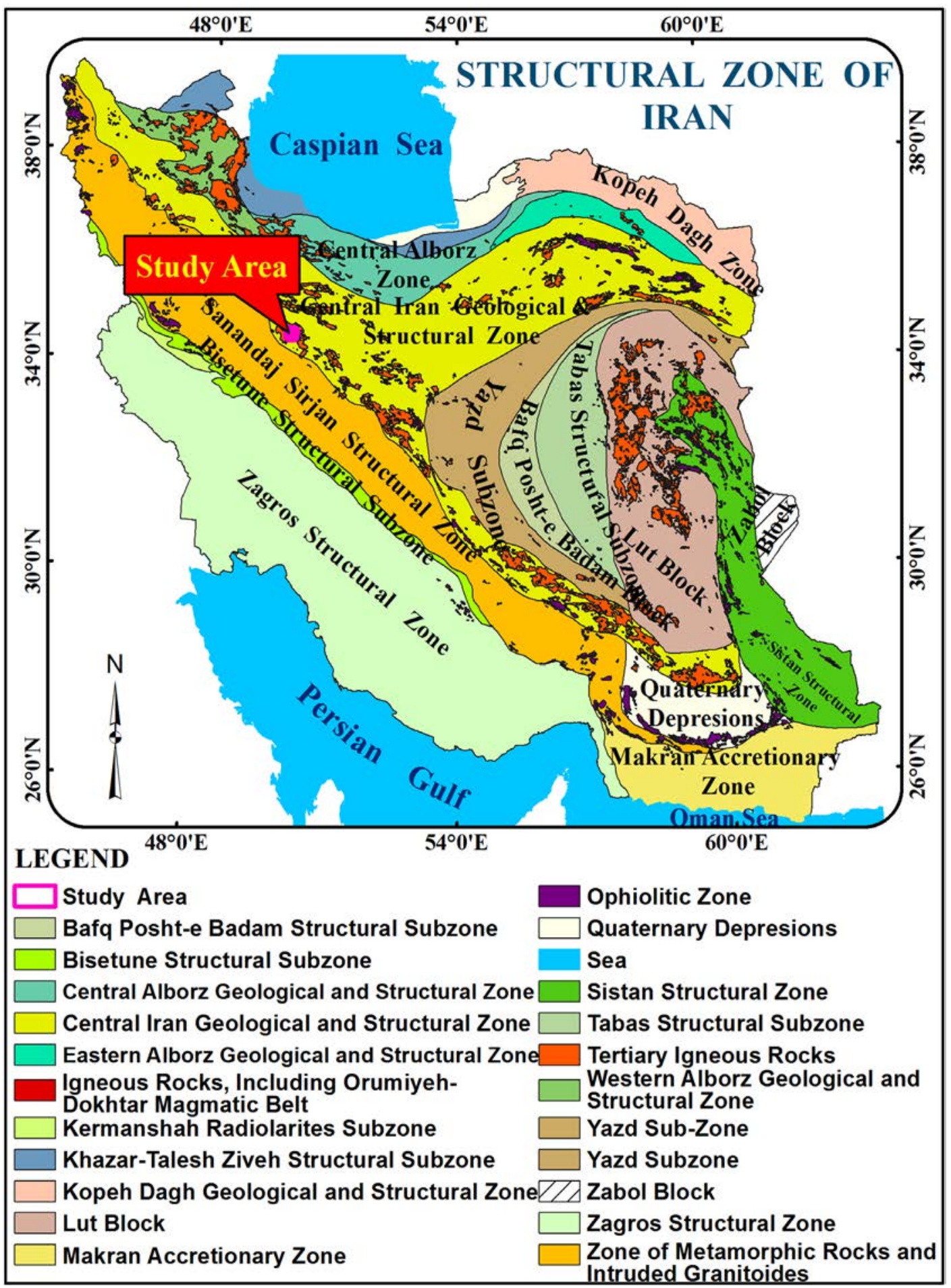

Figure 2. Location of Tafresh area scale 1:250,000 at structural zone of Iran (Sahandi, 2002).

period of time, magmatism had been taken place as separated that they have mostly basic to intermediate composition. Also, most of the Miocene rocks are distinguished by Qom Formation and Upper Red formation at Tafresh. Indeed, volcanic activities had been taken place as separated, and it is obvious that Quaternary deposits were formed remarkable part of study area as well.

In addition to the rocks units mentioned, several number of semi-deep and deep intrusive massive are identified 
that most important of which are Diorite, Quartz Diorite (Sarabadan intrusive massive), Microdiorite, Tonalite, and Granodiorite that most of this Western-Eastern intrusive massive were made outcrops in the Northeast part of Tafresh. Beside, some various kinds of dyke can be considered such as Diabase to Diorite, and Felsic (Figure 3).

In terms of extension and capacity, the volcanic-sedimentary collection is most significant and expansive rocks in the study area. Thereafter, sedimentary rocks of Triassic, Jurassic, and Cretaceous have most extension as well. Quaternary sediments covered exceptional part of area (Figure 4).

\section{Petrology of Volcanic Rocks}

Geochemical data and appropriate interpretation is so fruitful for informing about origin and assessment of considered rocks. So, 21 samples had been gathered from volcanic and plutonic rocks and dykes of study area which had least alteration. The major oxides and rare and minor elements were processed by ICP-MS and XRF technicians.

The intrusive rocks and dykes had been named base on $\left(\mathrm{Na}_{2} \mathrm{O}+\mathrm{K}_{2} \mathrm{O}\right) / \mathrm{SiO}_{2}$ diagram [7], and $\left(\mathrm{Na}_{2} \mathrm{O}+\mathrm{K}_{2} \mathrm{O}\right) /$ $\mathrm{SiO}_{2}$ was used for named of volcanic rocks [8] (Diagram 1 and Diagram 2).

Regard to Le bas diagram, the volcanic rocks of Tafresh are Dasite, Trachyte, Trachybasalt, Andesite, and Trachyandesite [6] (Diagram 1). Also, intrusive rocks and dykes of Tafresh have more Granite, Granodiorite, Diorit and Gabbro composition (Diagram 2).

Alkali diagram of $\left(\mathrm{Na}_{2} \mathrm{O}+\mathrm{K}_{2} \mathrm{O}\right)$ that is a cross to $\mathrm{SiO}_{2}$ was utilized for identifying nature of Tafresh' smagmatism rocks [9]. As result of this diagram, most of the Tafresh's samples were located in the alkaline and subalkaline. The subalkaline series encompass calc-alkaline and tholeits that can be separated using triangle diagram of Baragar and Irvine. So, most of the samples of Tafresh were limited in the calc-alkaline area. Also, most of samples had intermediate to high rate of Potassium (Base on the Gill Diagram 1981) [14] (Diagram 3).

Study of rare elements and rare earth elements has demonstrated that plenty of rare earth elements in the samples of Tafresh across to normalized Chondrite rocks. Hence, LREE elements enriched more than HREE elements. This poor quality of HREE was resulted of existing Garnet in the origin rock. Also, enriched of LREE elements can be produced by melted Felsic. The distributing of REE and Enriched LREE Elements showed that these rocks originated from upper mantel which is enriched these elements. As considerable issue is high concentration of $\mathrm{K}$ and $\mathrm{Rb}$ can be resulted by pollutions of crust and subtraction process. Also, negative anomaly of $\mathrm{Ti}, \mathrm{P}$, can indicate to continental rocks. Enrich of light rare earth elements in comparing to heavy rare earth elements is one of the considerable characteristics of calc-alkaline rocks of arc volcanos [10]. Indeed, emptying of $\mathrm{Eu}$ than Chondrite is characteristic of basic calcic rocks of volcanos in the continental active margin (Diagram 4).

With regard to volcano rocks of Tafresh, tectonomagmatic environment of Tafresh was characterized using

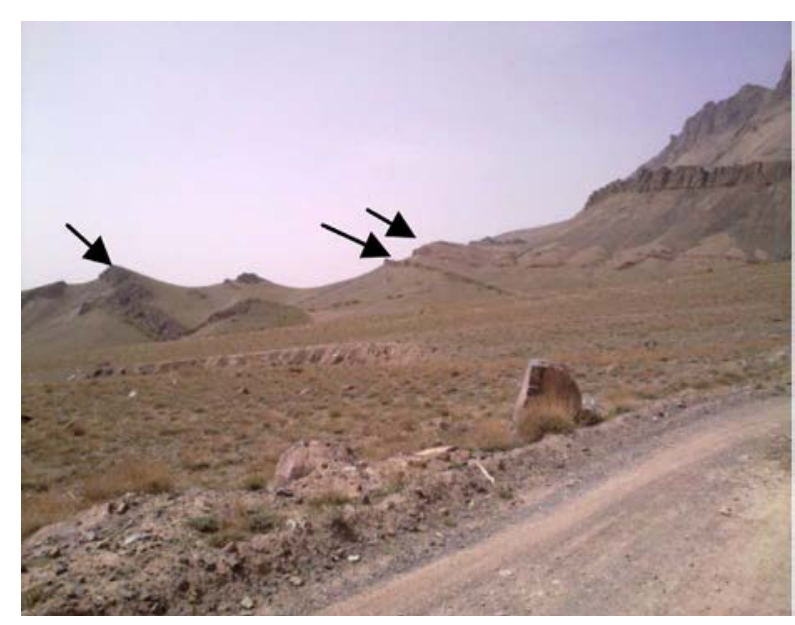

Sill outcrops

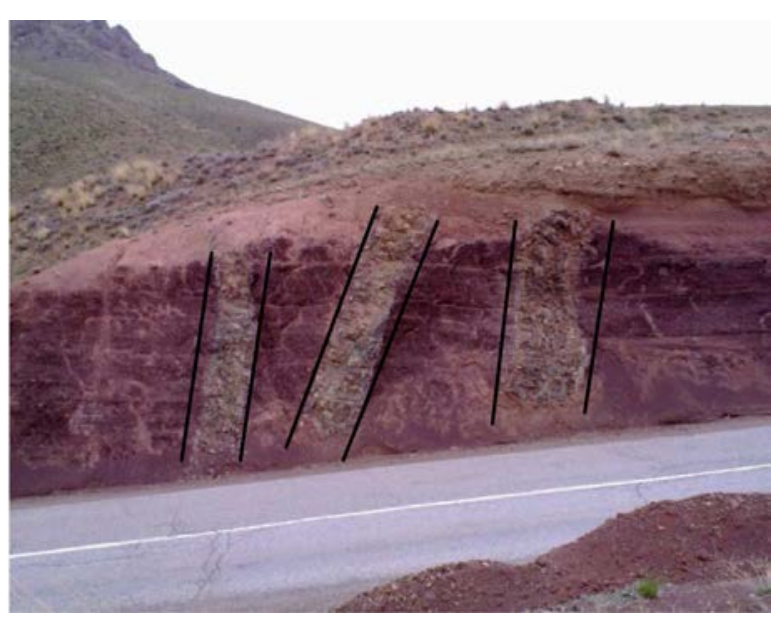

Dyke outcrops

Figure 3. Dykes and sills of study area. 


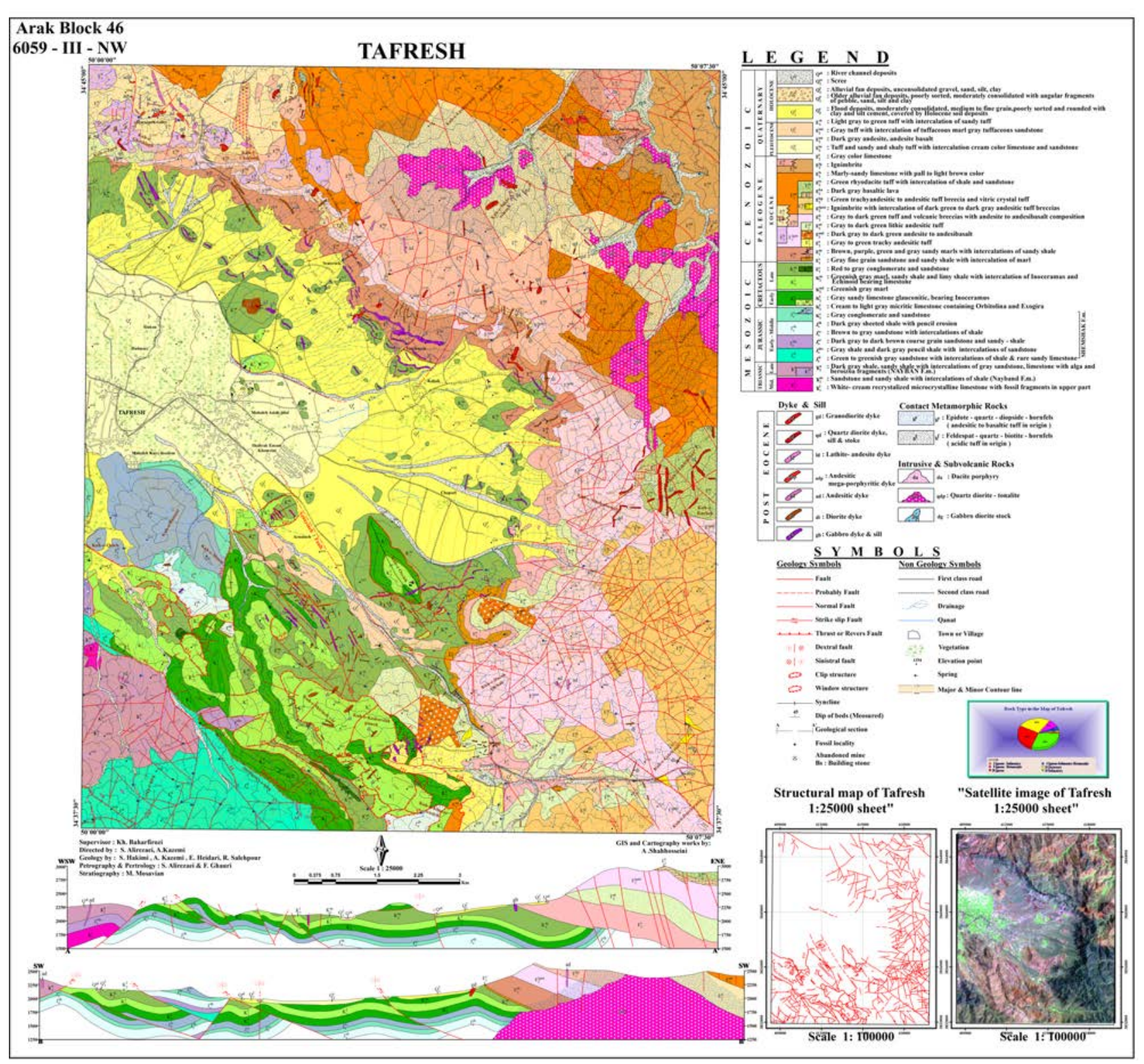

Figure 4. Tafresh's geological map scale 1:25,000 [13].

Gill (1981) and Pearce (1983). Base on Gill (1981) (La/Ba and La/Nb) most of the samples were situated in the environment of orogenic's Andesites (Figure 5). Depend on Zr/Y across to Zr diagram [11], most of samples of study area are associated with magmatic arc that was caused via subduction of oceanic plate under continental plate, just three of these samples were located in oceanic arc (Diagram 5 and Diagram 6). Also, plutonic rocks environments was distinguished by Pearce diagram (1983) which showed all samples are in the volcanic arc boundary (Diagram 7).

\section{Alteration}

Making dykes and plentiful intrusive massive had caused that metamorphic had been taken place. For instance, Pyroxene-Hornfels, Feldspar-Hornfels haloes that had around 200 - 500 m, Skarn collections had been formed by penetrating Sarabadan'sQuartzdiorite, which located in the Northeast of Geological Map of Tafresh, into the Basaltic to Andesitic tuffs and Acidic tuffs (Figure 5). Siliceous and argillic alterations were produced as spot that were associated withOligist, Garnet, and Epidote which had been made as well. Another intrusive rocks of 


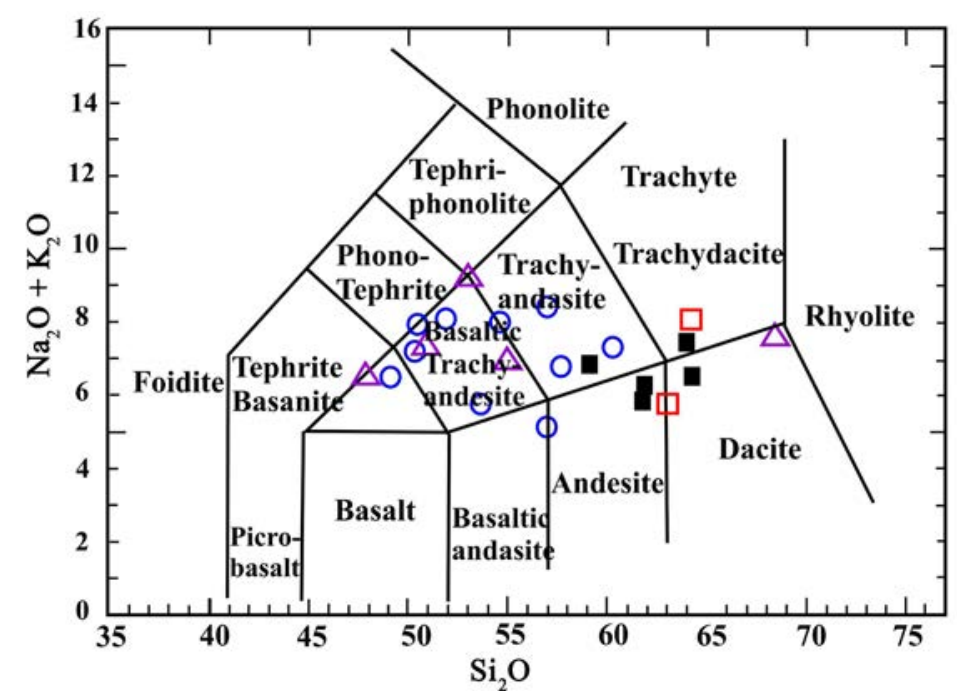

Diagram 1. Diagram of $\left(\mathrm{Na}_{2} \mathrm{O}+\mathrm{K}_{2} \mathrm{O}\right) / \mathrm{SiO}_{2}$ that is related to Le Bas et al. 1986 [8]. A Volcanic Rocks of Eocene, Plutonic Rocks of Post Eocene, 0 Plutonic of Eocene, Dykes.

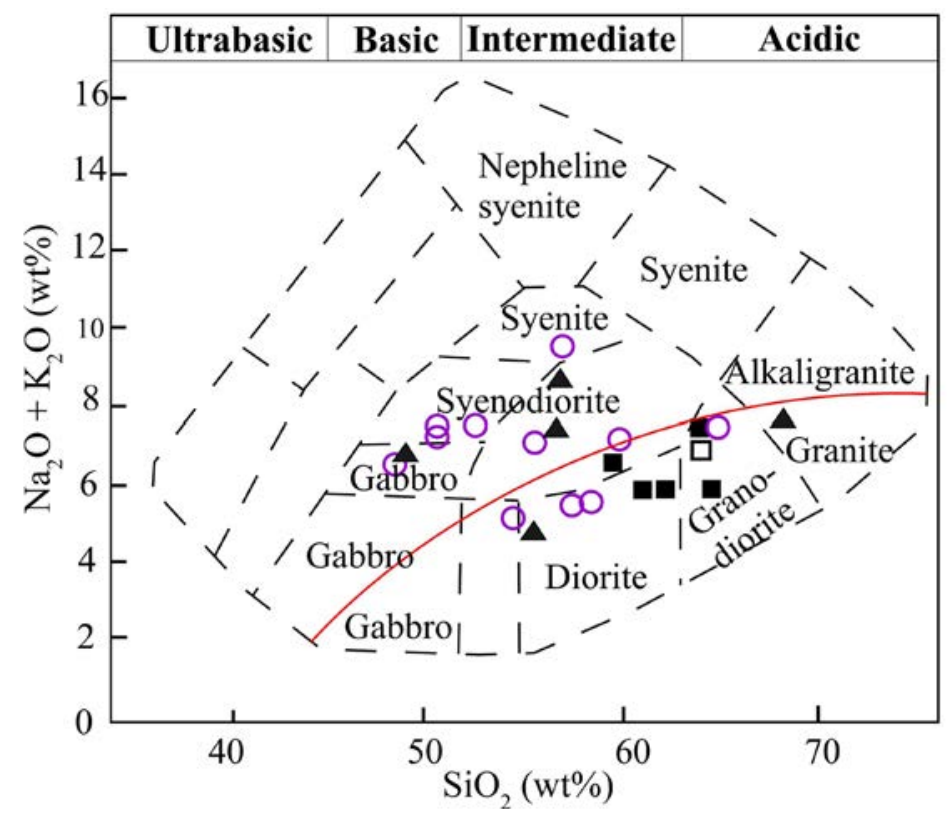

Diagram 2. Diagram of $\left(\mathrm{Na}_{2} \mathrm{O}+\mathrm{K}_{2} \mathrm{O}\right) / \mathrm{SiO}_{2}$ which is related to Cox et al. 1979 [7]. Volcanic Rocks of Eocene, Plutonic Rocks of Post Eocene, $\mathbf{\square}$ Plutonic of Eocene, $\mathbf{0}$ Dykes.

this area is Qaleh Tous's Gabbro-Diorite stock ( $\mathrm{dg}$ ) at north of Tafresh's geological map that was penetrated into the E2an collection. Also, petrography studies have shown this unit has a myriad of Epidote and Chlorite alterations base on the samples of this unit.

Argillic and Iron Oxide alterations of area that was related to acidic units of Eocene involved Argillic, Kaolinite, and Fe oxide alterations such as; Limonite, Hematite, Goethite. Epidote minerals were seen into the basic and intermediate volcanic as well. Other alterations that have been observed is Sulfide, Hydrothermal Fe oxide, and Propylitic like Epidote and Chlorite. Also, Eocene units were influenced via massive with Diorite and Granodiorite compositions, and produced lots of alterations. These alterations are Endogenic kind and involved Pyrite, Siliceous, Kaolinite, and in some of locations were produced Iron Oxide. Indeed, in the road of Kahak forward 


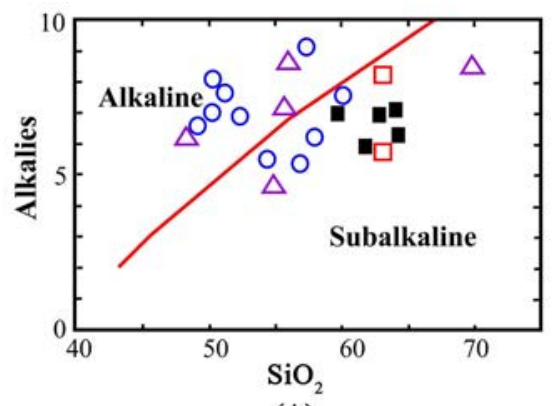

(A)

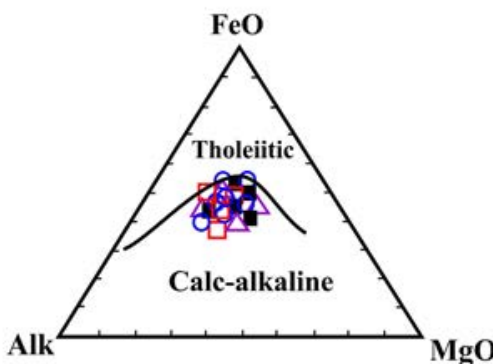

(B)

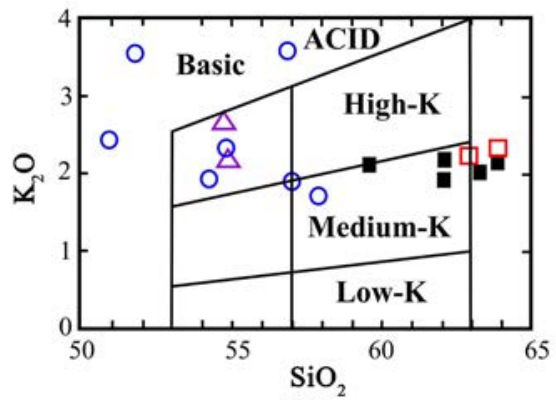

(C)

Diagram 3. Diagram for distinguishing magmatism series in tafresh. (A) Alkaline in front of $\mathrm{SiO}_{2}$ Irvan and Baragar (1971). (B) Triangle diagram of Irvan and Baragar (1971) [9]. (C) $\mathrm{SiO}_{2} / \mathrm{K}$ Gill (1981) [14]. $\mathbf{A}$ Volcanic Rocks of Eocene, Plutonic Rocks of Post Eocene, $\mathbf{Q}$ Plutonic of Eocene, Dykes.

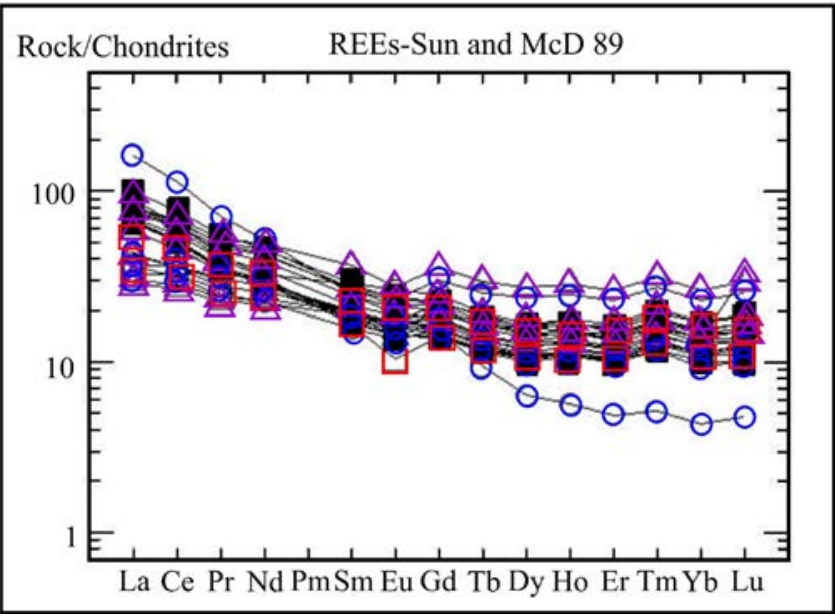

Diagram 4. Spider diagram of tafresh's rocks for demonstrating rare earth elements that were normalized in contrasted Conderite. Coderite data Sun and McDonough 1989 [17]. A Volcanic Rocks of Eocene, Plutonic Rocks of Post Eocene, $\square$ Plutonic of Eocene, Dykes. 


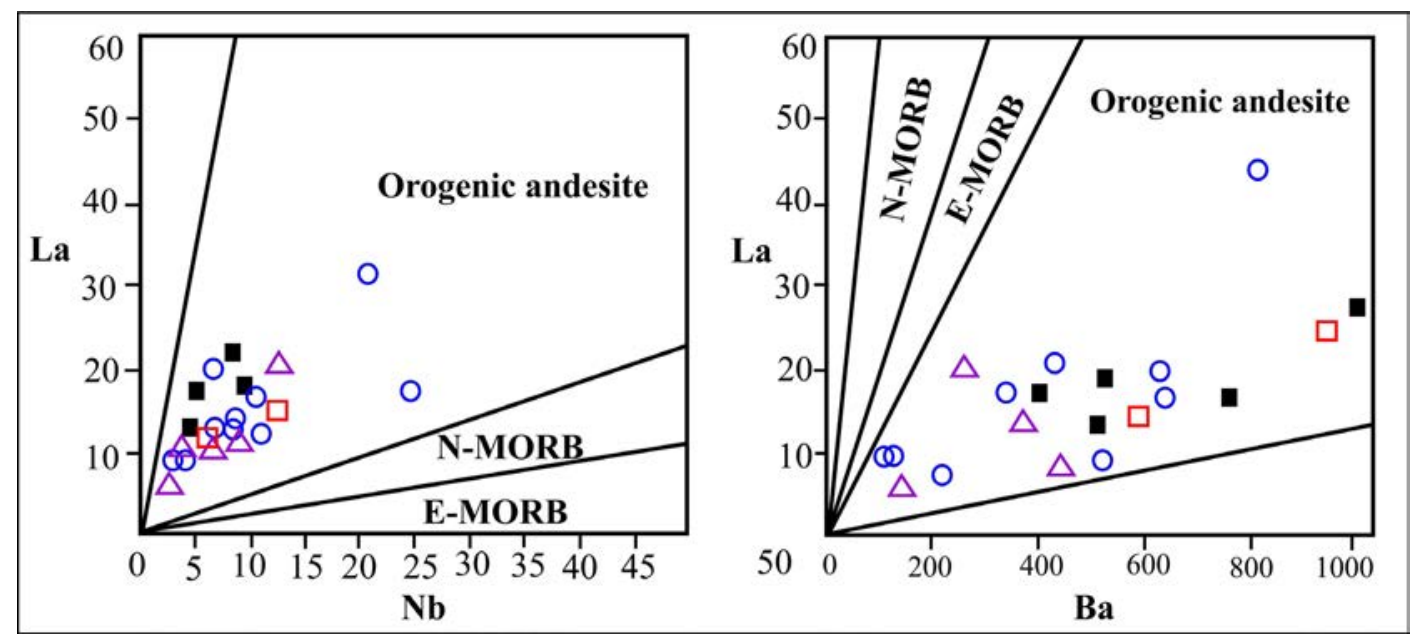

Diagram 5. La/Nb and La/Ba, based on Gill1981 [14]. A Volcanic Rocks of Eocene, Plutonic Rocks of Post Eocene, $\square$ Plutonic of Eocene, Dykes.

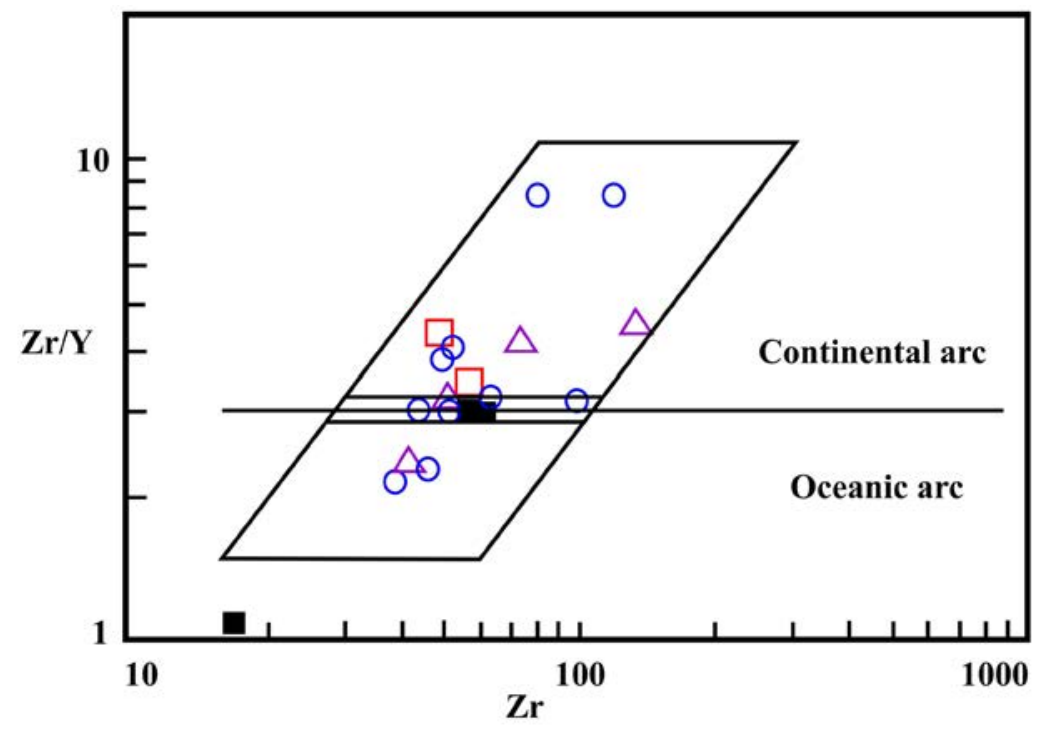

Diagram 6. Zr/Y than Zr, based on Pearce, 1983 [11]. A Volcanic Rocks of Eocene, Plutonic Rocks of Post Eocene, $\square$ Plutonic of Eocene, 0 Dykes.

to Sarababdan, some of Skarn had been formed by penetrating Granite intrusive into the tuffaceous units or acidic lava. Epidote, Magnetite, and Pyrite are some minerals of Eskarn that were found at this area. Also, some of sedimentary units were become siliceous which were related to volcanic and intrusive units.

\section{Relation between Tafresh's Volcanic Rocks and Alterations}

Most of the mineralization had been showed of Tafresh are Dacite, Diorite, and Tonalite and Andesite dykes. Only the tremendous intrusive massive of Sarabadan's Quartzdiorite and Tonalite which was located at Northeast of area had monumental alteration zones, and it caused that some of Pyroxene-Hornfels had been produced into the Basaltic and andesitic tuffaceous rocks and Feldspar-Hornfels was formed into acidic tuffaceous rocks as well (Figure 6).

Porphyry Dacite massive that located at Northeast as two small massive are younger in compering to Sarabadan's massive. Another intrusive massive can be observed in area is Gabbrodiorite (dg) Stoke of QalehTus. This stoke was penetrated into the E2an unit that encompassed Andesite, metamorphed Andesitic Basalt that caused Epidote and Cholorite alterations were produced into the mentioned unite. Most of the volcanic rocks of Tafresh 

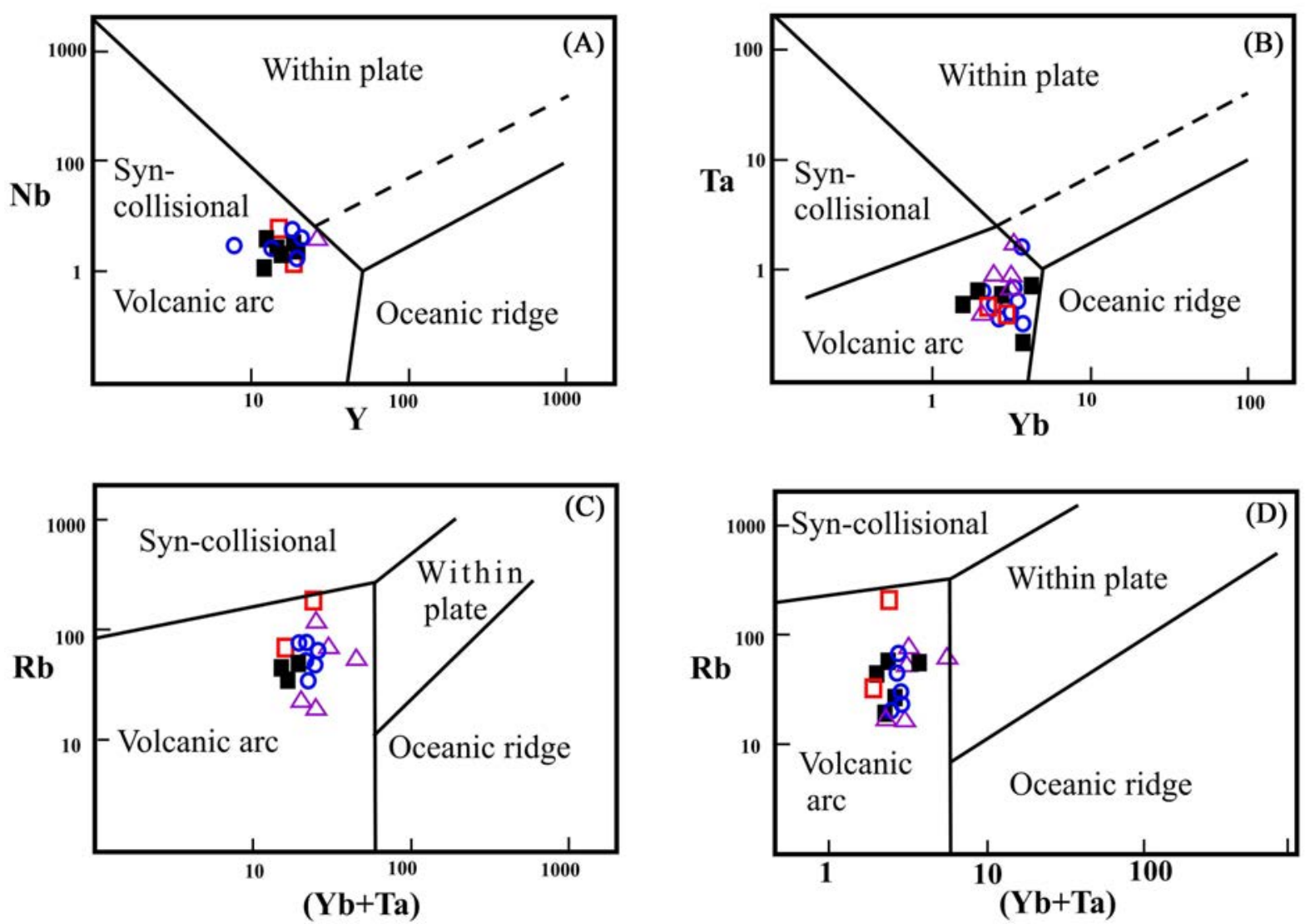

Diagram 7. Bb/Y, Ta/Yb, $\mathrm{Rb} /(\mathrm{Y}+\mathrm{Nb}$ and $\mathrm{Rb} /(\mathrm{Tb}+\mathrm{Ta})$ diagram, Piers 1984 [11]. $\mathbf{\Delta}$ Volcanic Rocks of Eocene, $\mathbf{P l u}-$ tonic Rocks of Post Eocene, 0 Plutonic of Eocene, Dykes.

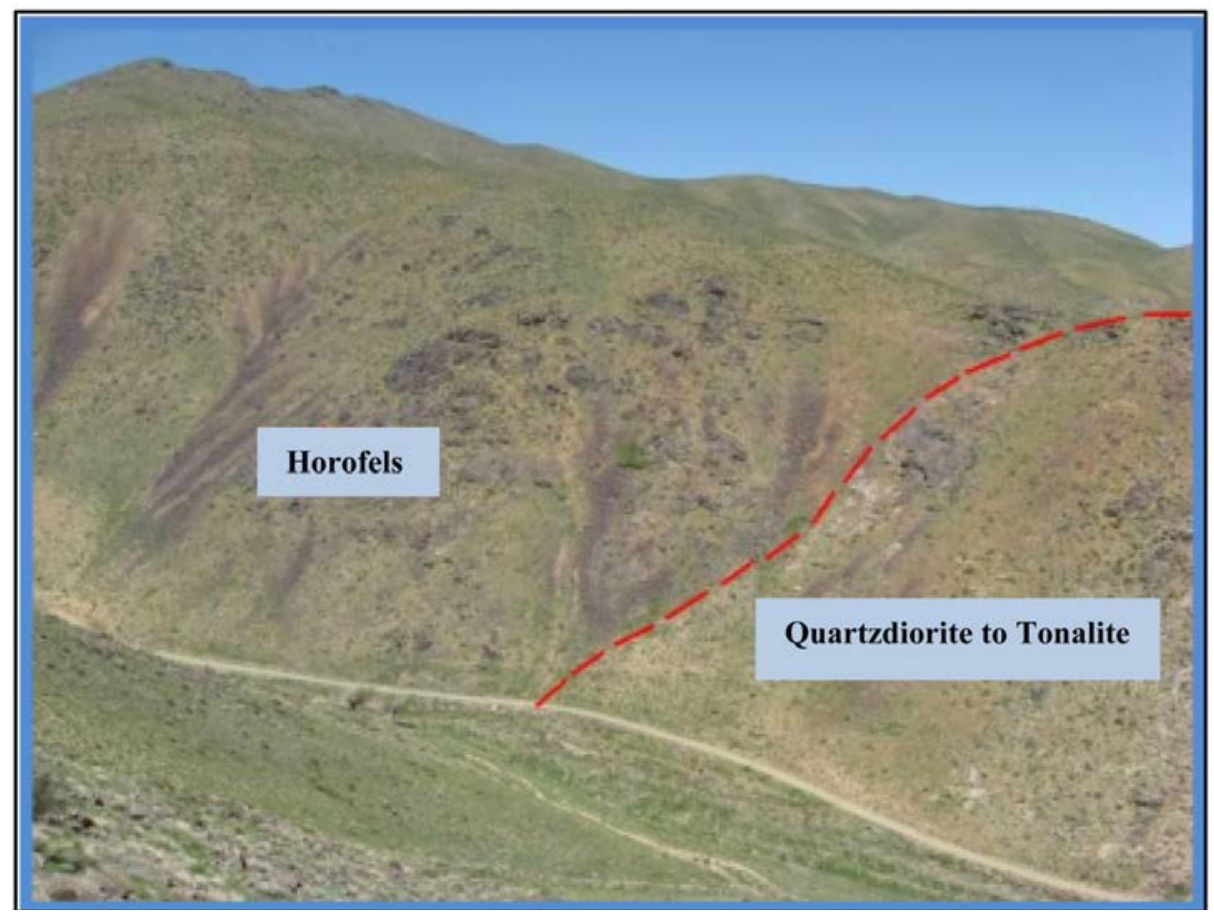

Figure 5. View of acidic tuffs that were become Hornfels in margin of Sarabadan's Quartzdiorite intrusive massive. 


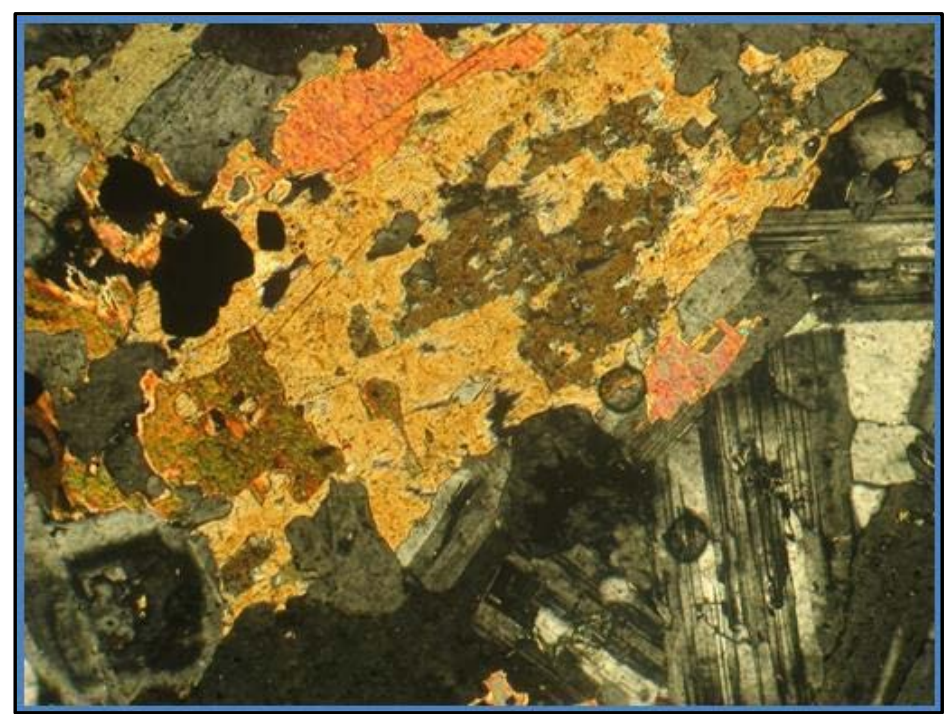

Figure 6. Fulling of fractures of rocks by diopside.

were become altering which include mostly Siliceous, Calcite, Sericite, Chlorite, and Epidote alterations that were associated with mineralization in this area (Figures 7-12). Tafresh has seven kinds of intrusive massive with various composition such as Gabbrosills and dykes, Diorite dyke, Andesite, Mega Andesite, some dykes with Andesite-Latite composition, Quartzdiorite dykes, and micro Granodiorite dykes. Furthermore,

Gabbro dykes and sills (gd unit) made lots of Carbonate, Sericity, Security, Chlorite in the Tafresh. Lots of Iron Oxide and Titan along with dykes were observed into the microscopic sections (Figures 7-9).

Most of the alterations were seemed is related to Diorite dykes (di unit). These dykes had been penetrated next to the Gabbro dykes in Tafresh which produced tremendous alterations of Epidote, Chlorite, Sericity, Carbonite alterations (Figure 10).

Some of Andesite dykes (ad unit) produced carbonate-serisity alteration and siliceous and sedimentary rocks made alteration around themselves as well. These alterations are almost along with Iron Oxide and Titanium (Figure 11).

Mega-porphyry Andesite dykes cab be observed that had porphyritic tissue with micrity-halomicrogranounalr with low alteration (Figure 12).

Also, Andesite-Latite dykes (Id unit) had been observed at Northeast of Tafresh, and in some parts of area along with these dykes were produced lots of Sericite, Carbonate, as well as a little Epidote and Chlorite. Indeed, in this area was observed Hornblende crystals, Iron Oxide, and Free Titan (Figure 13). Propylitic alteration into the Andesite Latite caused that Amphibolite and Chlorite were turned out to Calcite, Chlorite, and much little Epidote (pistasitezoisite). Blades of Sericite were found among Feldspars. Also, vein and veinlets of Epidote were formed in Andesite rocks.

Another kind of dykes in this area is Quartzdiorite dykes (qd) which they had remarkable extension at East, Northeast, and North. Most of these dykes had formed in delayed phases of Tunalite-Quartzdiorite of major massive of Sarabadan. These dykes have much more alteration zones such as Epidote, Chlorite, Calcite, and Sercite compared to other dykes (Figure 14).

Ultimately, Micrograno-Diorite dykes (gd) had been produced at latest steps of formation of intrusive massive with regard to field relation of these dykes and other rocks units of this area and cutting of Andesite dykes and Eocene units. Alongside, these dykes, some of secondary minerals were formed such as Calcite, Sericite, Iron Hydroxide, Chlorite, and Argillic minerals (Figure 15).

According to survey of microscopic samples and existing witness of field, hydrothermal solutions had influenced on the study area via faults and tectonic structures of area as Olivian minerals of basaltic rocks had been turned to Serpentine. In some cases, Opak minerals were turned to the Iron Hydroxide as well. By the way, in the volcanic rocks, Feldspars have been turned somewhat to Argillic, Calcite, Epidote, and Chlorite. In location of destroying of Ferromagnesian Rutil and Sphene minerals were observed and Sericitic is observed as blades 


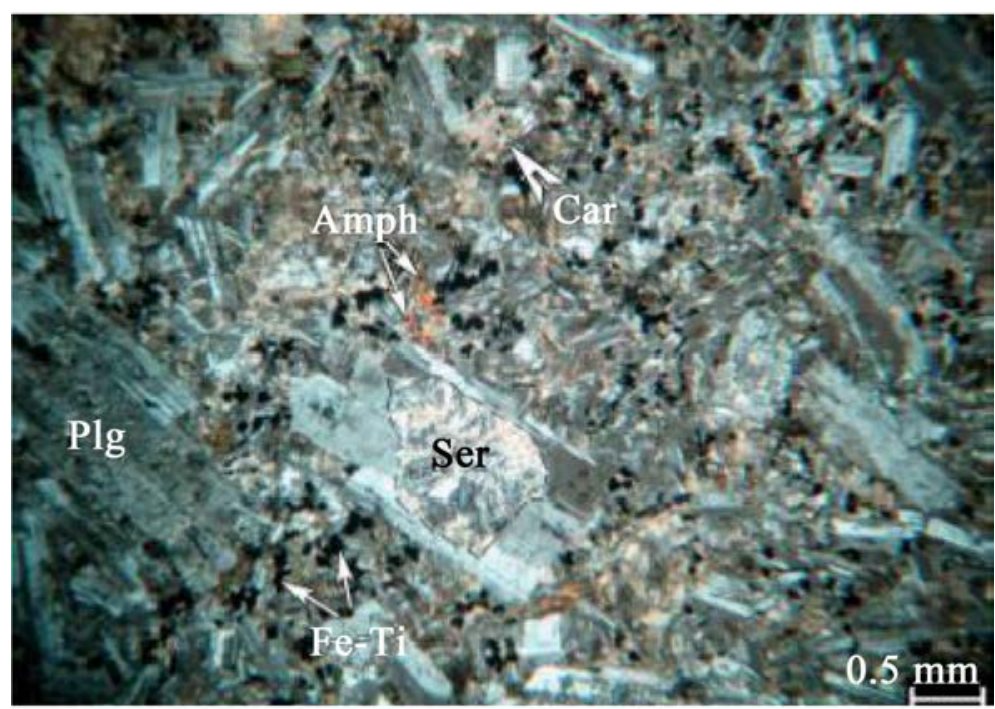

Figure 7. Linear crystals of plagioklas and clinopyroxene into the tiny grain texture of plagioklas (plg) and pyroxene a long with Siricitic (ser)-Carbonate (car) alterations (XPL).

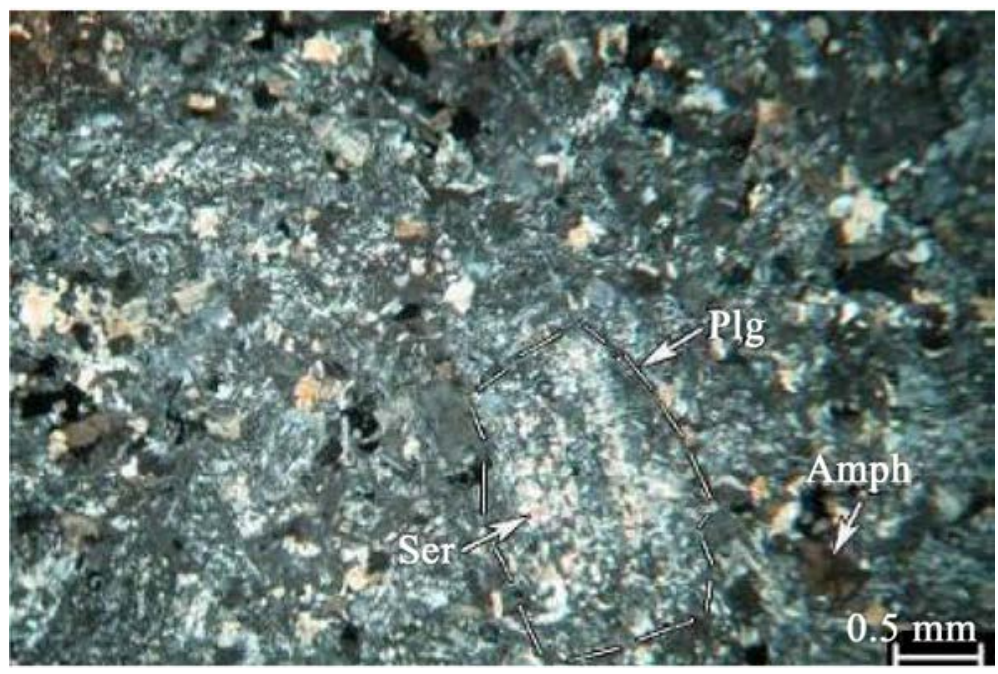

Figure 8. Minuscle grain Gabbro along with subefinitic to granular with major minerals of plagioklas (plg), pyroxene and hornblende minor minerals and sosority alteration (ser) (XPL).

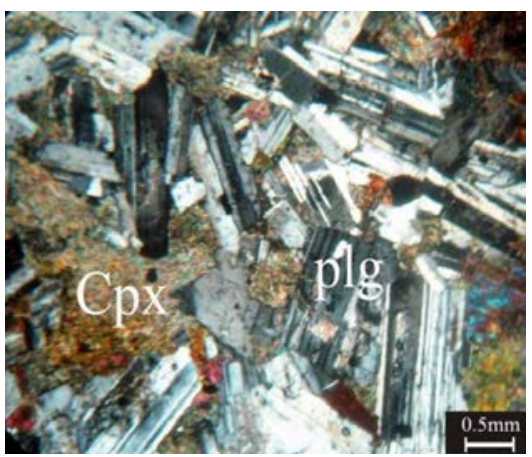

(A)

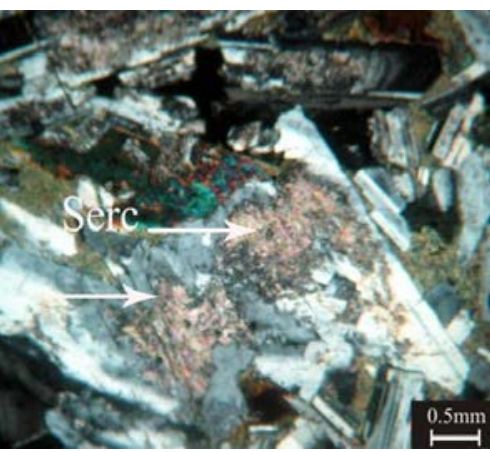

(B)

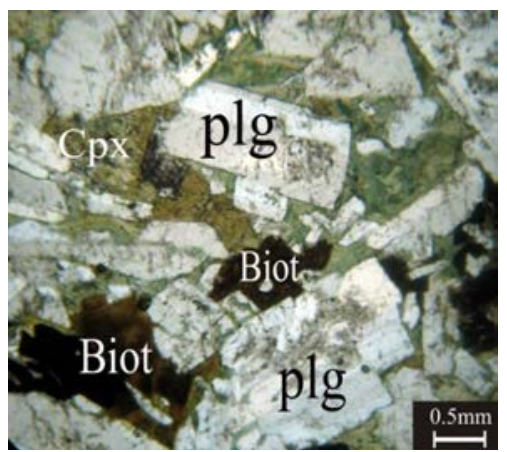

(C)

Figure 9. Samples of Gabbro dykes. (a) Linear crystals of plagioklas in various directions along with clinopyroxene. (b) Selective sericite into the plagioklas. (c) Changing clinopyroxene to oralit along with biotite. 


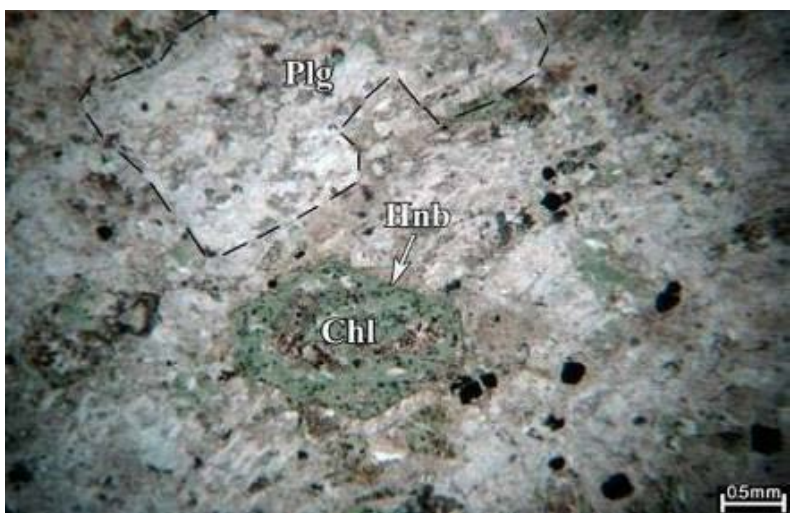

(A)

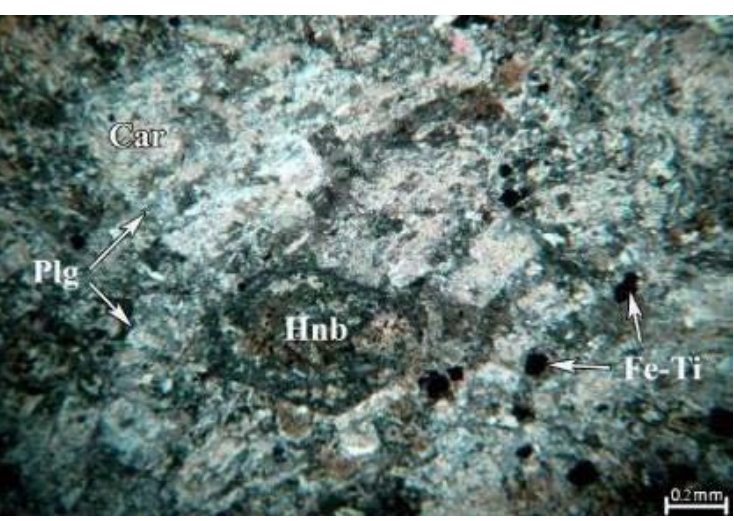

(B)

Figure 10. (a) Plagioklas and hornblende phenocryst into the minute to intermediate texture of feldspar, quartz and ferromagnesian minerals (XPL), (b) Hornblende crystal that became thoroughly chlorite and virtually carbonate (PPL).

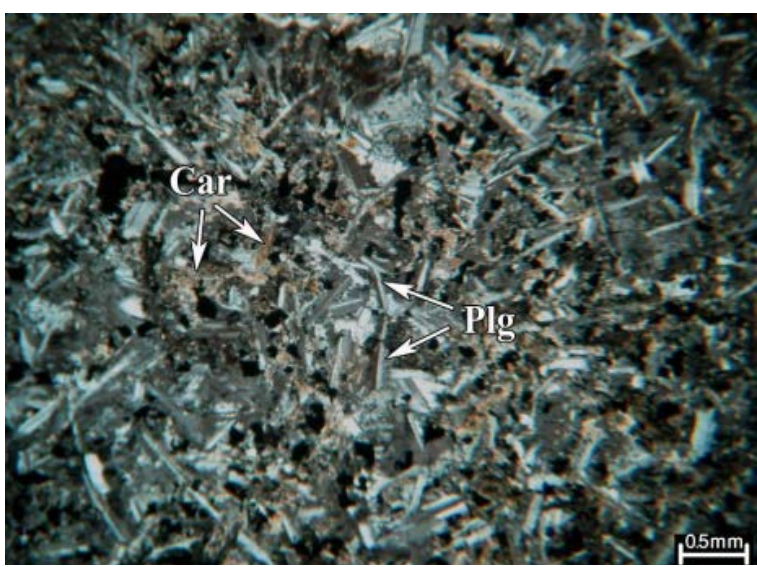

(A)

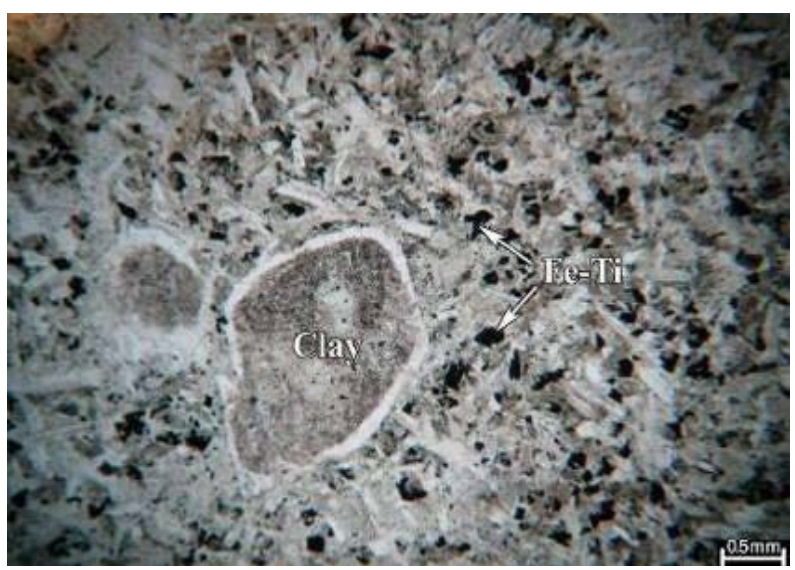

(B)

Figure 11. (a) A myriad of microlites of Feldspar in the minuscule texture (XPL). (b) Alterations of siricitic-carbonate and iron oxide and titanium (XPL).

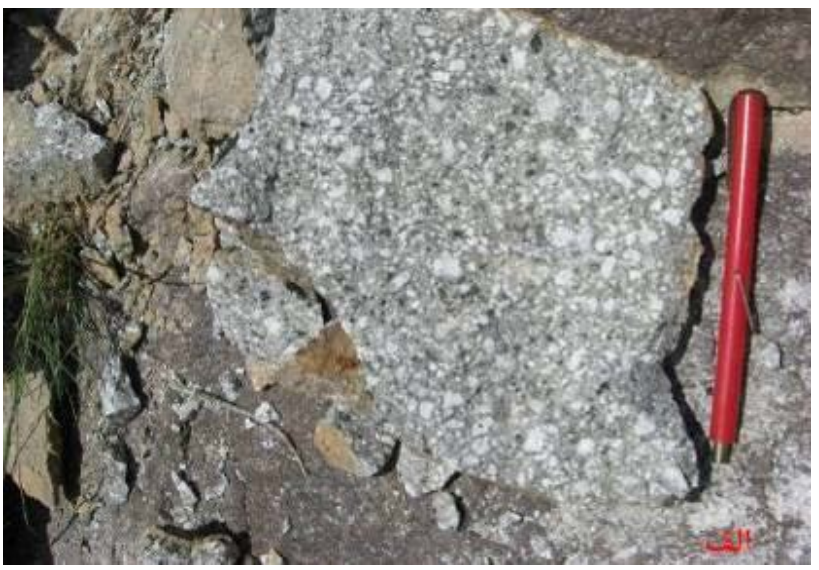

(A)

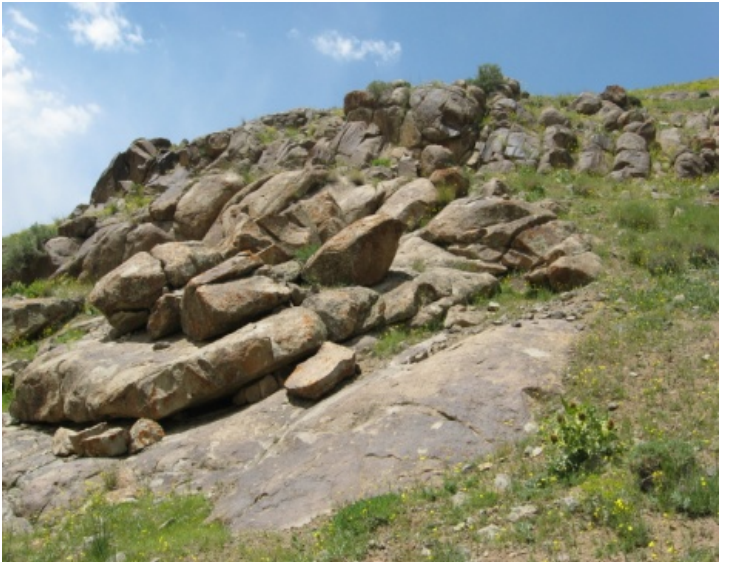

(B)

Figure 12. (a) Porphyritic tissue and large crystal of plagioklas, amphibolite and biotite into the megaporphyry andesite texture. (b) Near view of outcrops of megaporphyry andesite.

among Feldspar minerals. 


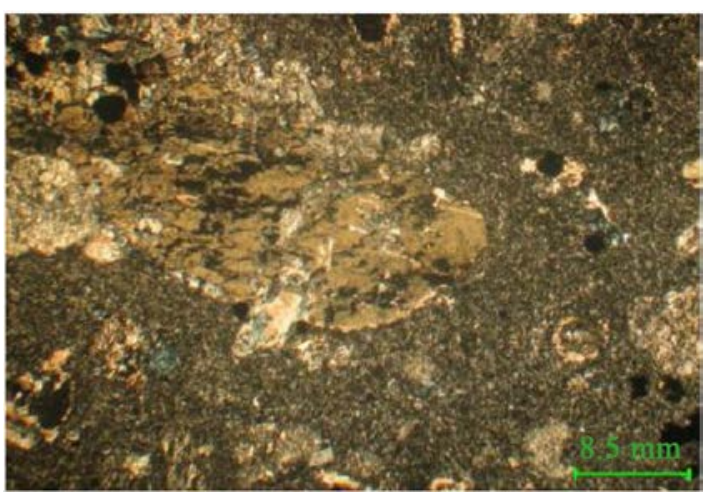

Figure 13. Samples of Andesite-Latite, chlorite and calcite alterations into the hornblende.

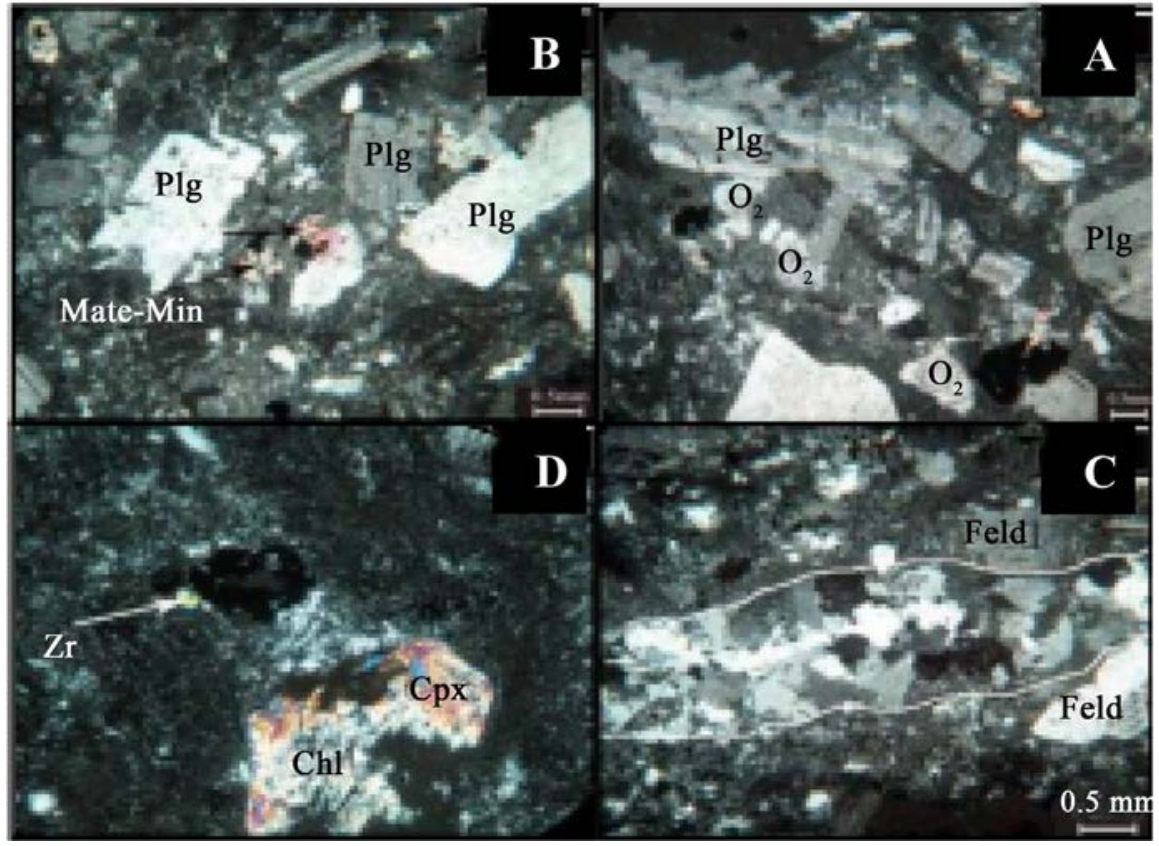

Figure 14. (A) Sample of qd dykes with Tonalite-Dacite composition (B) Large crystals of plagioklas into the vitreous to tiny crystal dough, remains of $\mathrm{Mg}$-Fesilicates that were turned to the chlorite. (C) Siliceous alteration as veinlet. (D) Turing of Clinopyroxene.

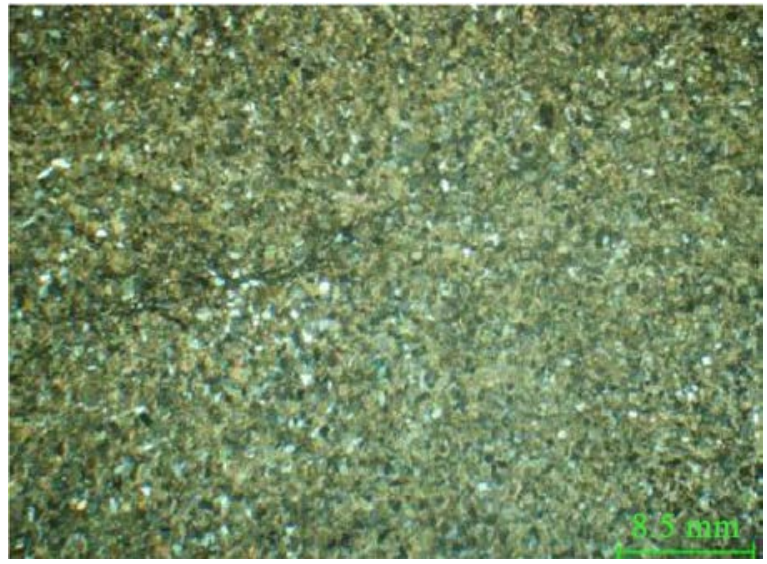

Figure 15. Microscopic view of microgranodiorite dyke (XPL). 


\section{Processing Satellite Images and Detecting Alteration Boundaries}

Boundary and type of alterations were identified by processing ETM +7 and Aster satellite images. In this regard, several methods were used such as Band Ratio and Match Filtering. As overall trend, in result of processing of satellite images, two kinds of liniments were identified that one of which was deep liniments such as major faults. This kind of liniments encompassed large liniments of study area that most of mineralization and motions of magma were fulfilled via these deep liniments. Another kind of liniments of study area was minor liniments that whereby mineralization had been concentrated on the various locations by these minor liniments like minor faults and fractures (Figure 16). Eventually, location of liniments has coincided with Thrust,

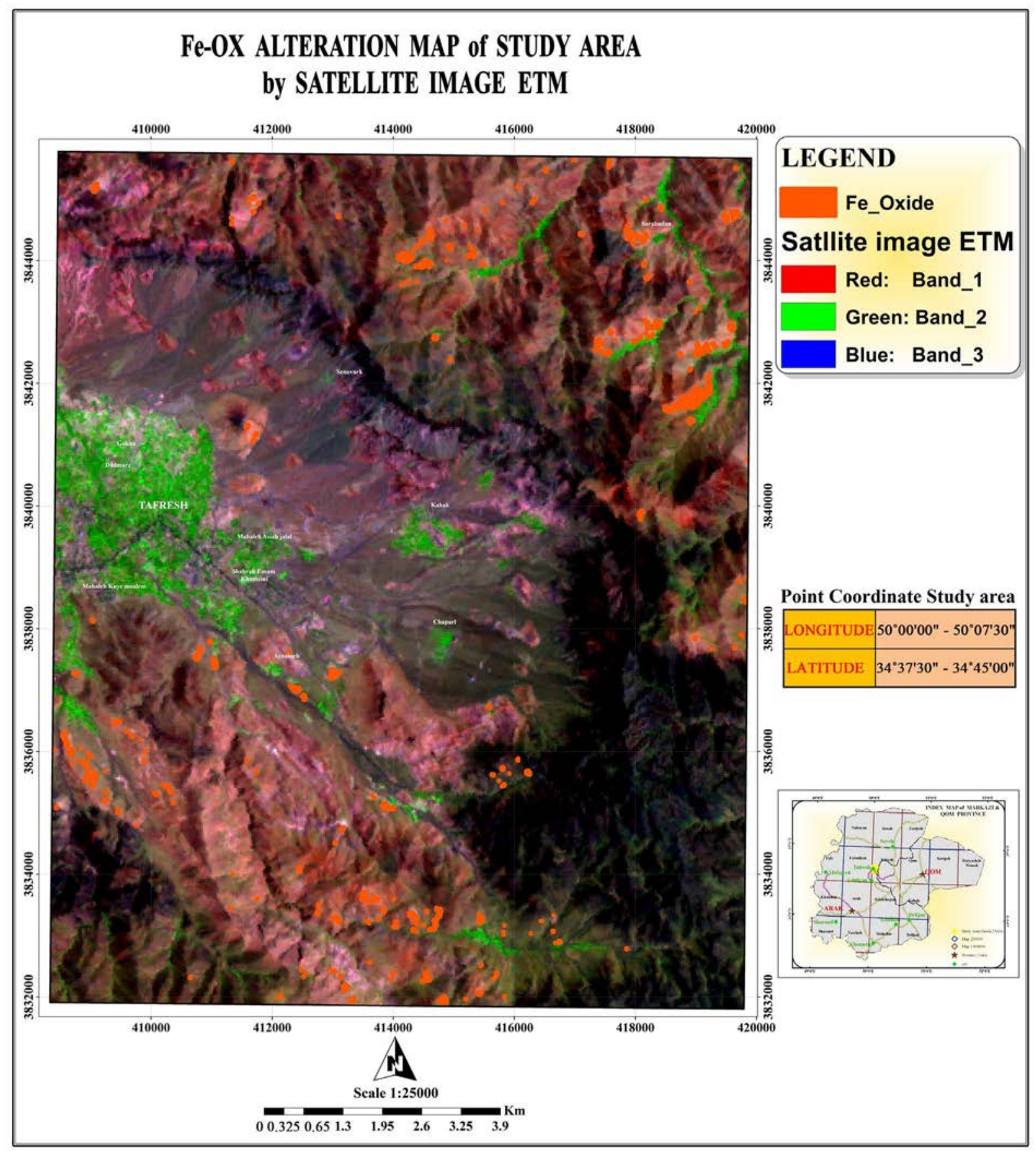

Figure 16. Major and minor liniments of Tafresh [15]. 
Strike Slip, and Normal faults of Geological Map of study area.

As a whole, incorporating all of alterations and structures, which were resulted from processing satellite images, showed diversity, extension, and concentration of alterations took place at Southwest of study area that they are related to Diorite and Gabbro dykes. As matter of fact, Siliceous, Propylitic, and Argillic alterations were concentrated on Southwest parts (Figure 21) and it is noteworthy that most of Sericitic alterations of study area were located at East of area that are associated with Microgranodiorite and Quartdiorite dykes.

In the meanwhile, minerals of Argillic, Sericitic, Chlorite, Epidote, and Carbonate were considered in some parts of North and Northeast of study area that all of which can be related to low Sericitic-Propylitic. These alterations that had influenced Andesite-Tuff volcanic units and Teracy Andesite that are able to disclose amount of effectiveness of alterations' Sericitic, Propylitic, and Chlorite (Figures 17-22).

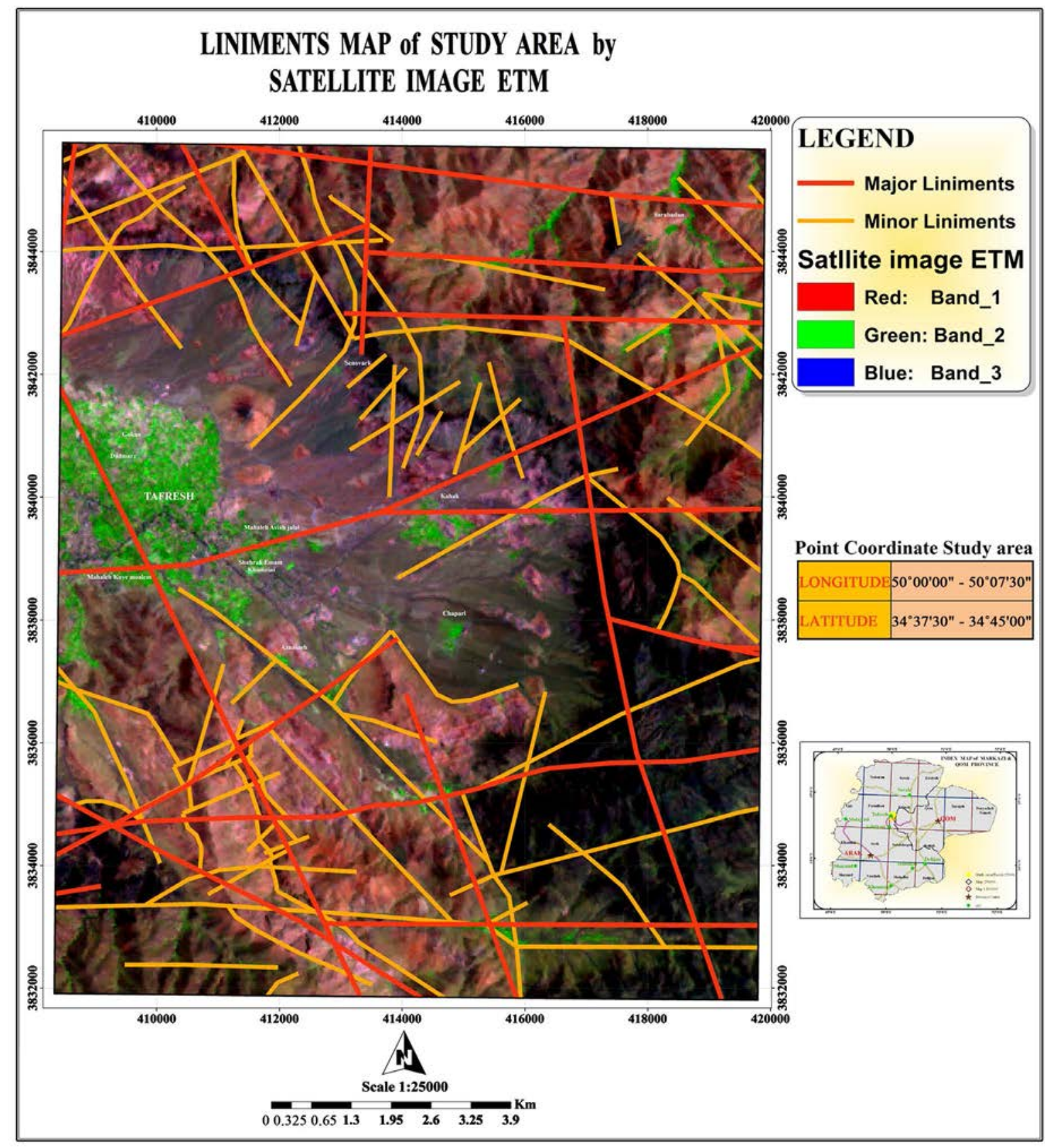

Figure 17. Fe oxide alterations [15]. 


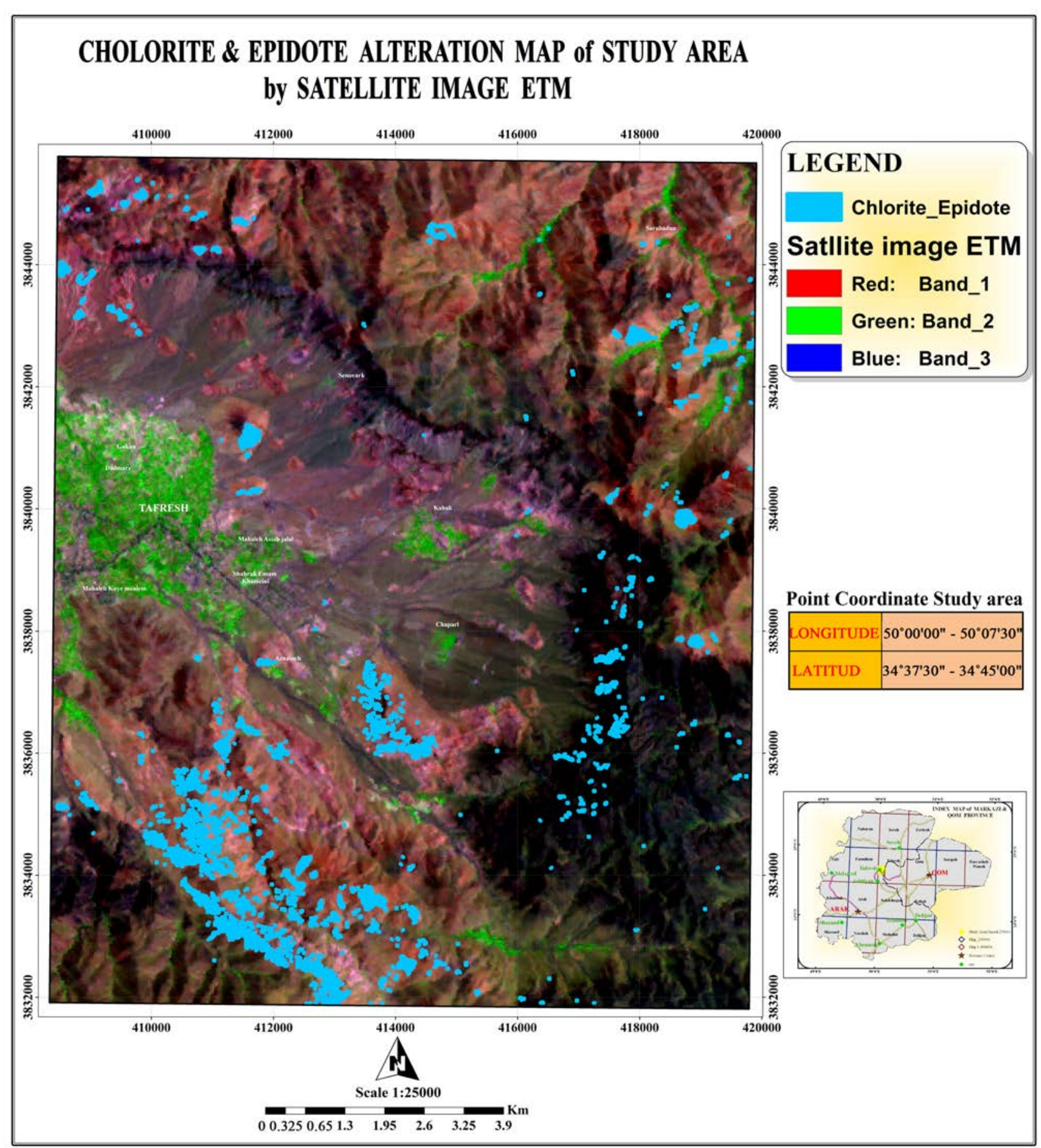

Figure 18. Epidote-chlorite alterations [15].

\section{Tectonic of Tafresh}

Stratigraphy's data and relationships between rock units in Tafresh area showed several numbers of orogenic events were taken place in the various period of time such as Late Cretaceous, Late Eocene, Late Miocene, and Late Miocene-Pliocene. According to type of deformation, Tafresh area can be divided to two parts (Figure 23).

1) Boundary of Volcanic rocks of Eocene that have occupied most part of Northeast and Southeast of Tafresh is devoted to these rocks. This area had been influenced by tremendous intrusive massive that has composition 


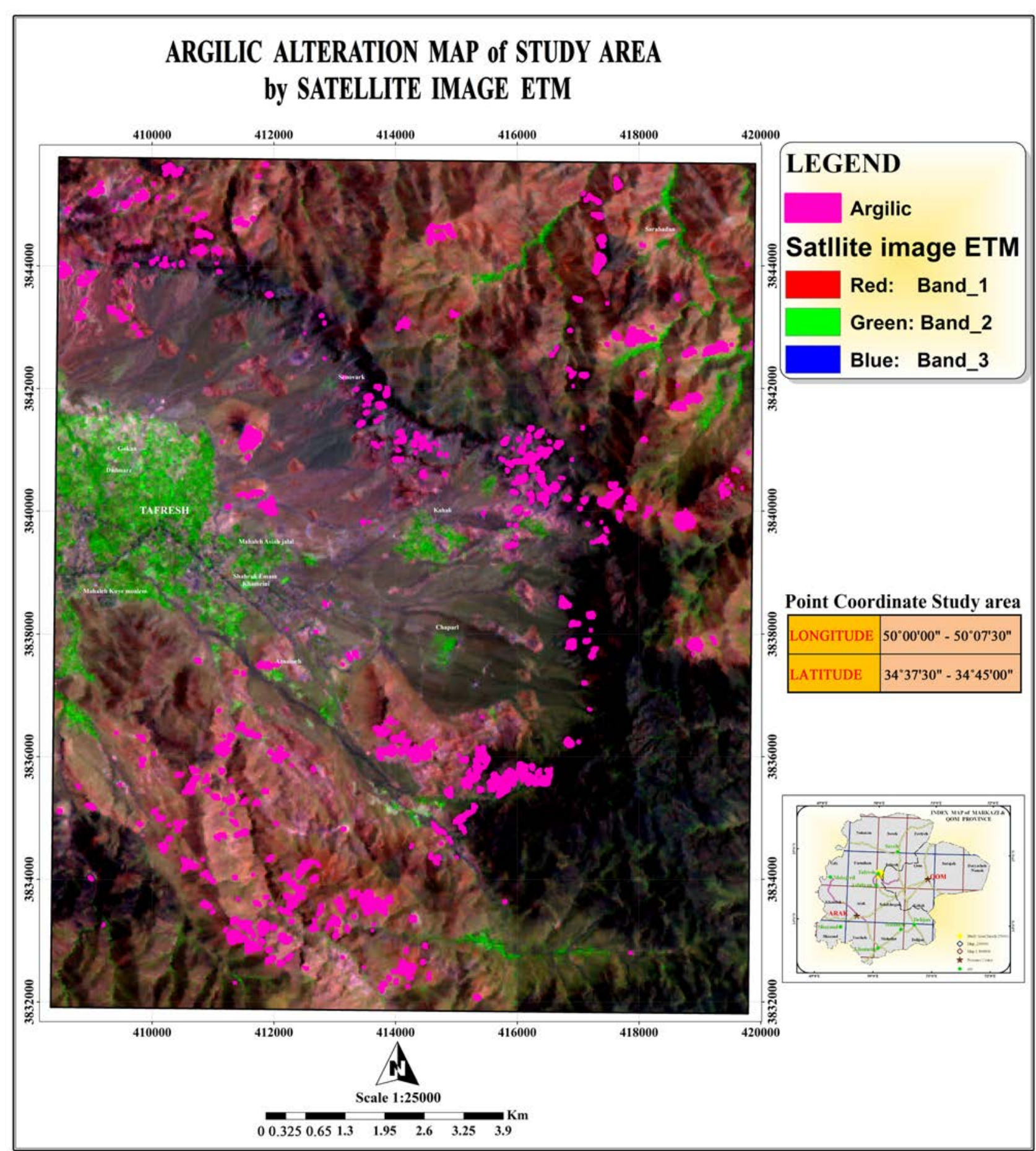

Figure 19. Argilic alterations [15].

of Granodiorite to Diorite and thereby lots of Hornfels had been produced in the volcanic rocks. Also, common procedure of operation of enrgies in this area is Southeast-Northeast that caused most of the faults of this area are brutal. As such, these faults can be distinguished as four types of operation like Southeast-North-west, Southwest-Northeast, Western-Eastern, and Northern-Southern. Furthermore, most of rock units of this area encompass tuff, volcano sedimentary and volcanic rocks.

2) Boundary of outcrops of Mesozoic rocks at sought and West of Tafresh area. In this area, folding of rocks 


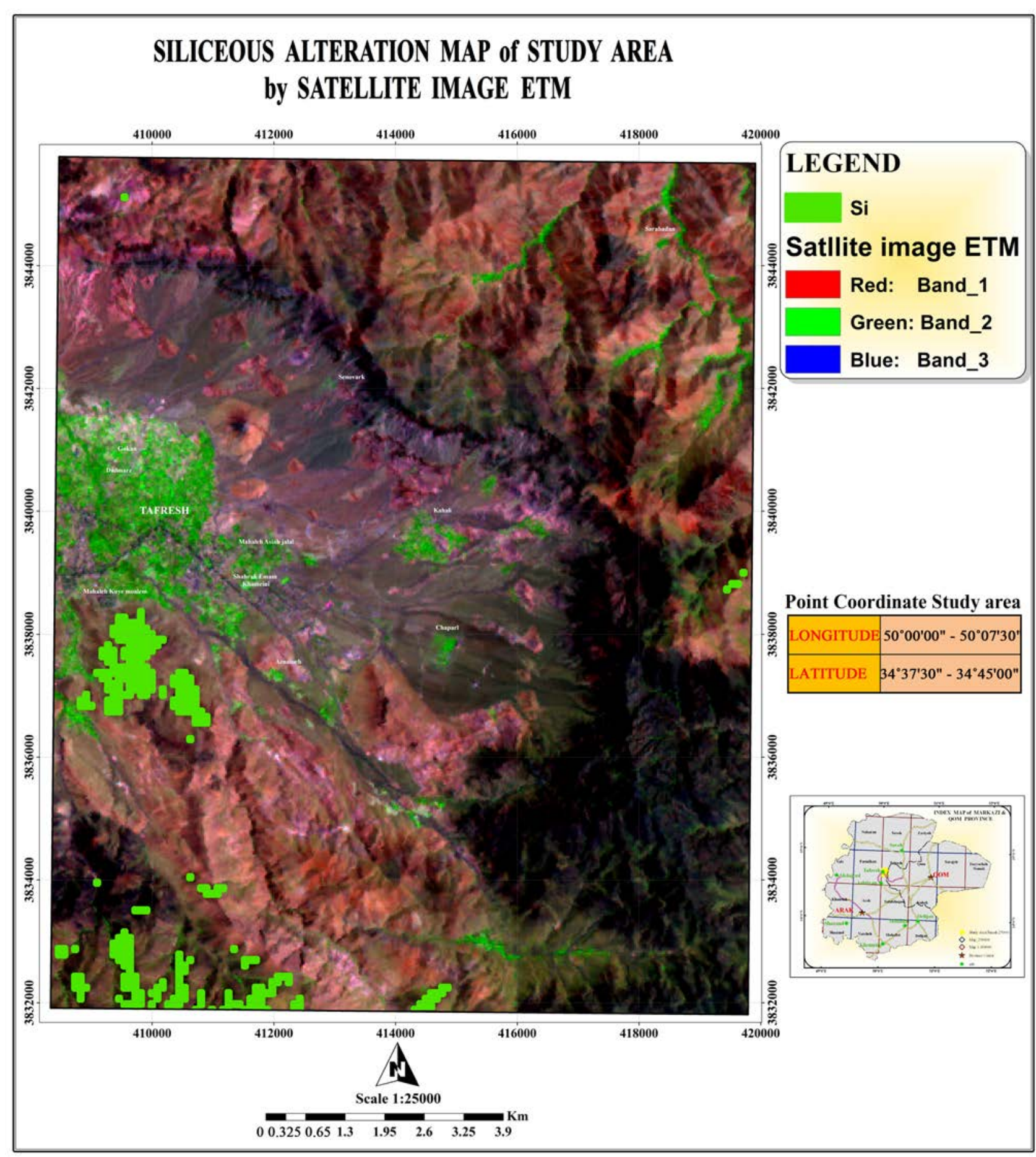

Figure 20. Siliceous alterations [15].

is a long with faulting. Most of rocks are sedimentary with folding are mild and open axis. Meanwhile, faults of this area had been formed in varied tectonic phases which unlike faults of Western and Northern, in this area, faults had various kinds of operations such as Thrust, Normal, and Strike Slip.

In addition, three kinds of normal fault were identifies that one kind of which had been formed by vertical motions due to penetrating magma into the Eocene rock unites. This kind of faults can be effective agent for producing widespread alterations and mineralization at study area. 


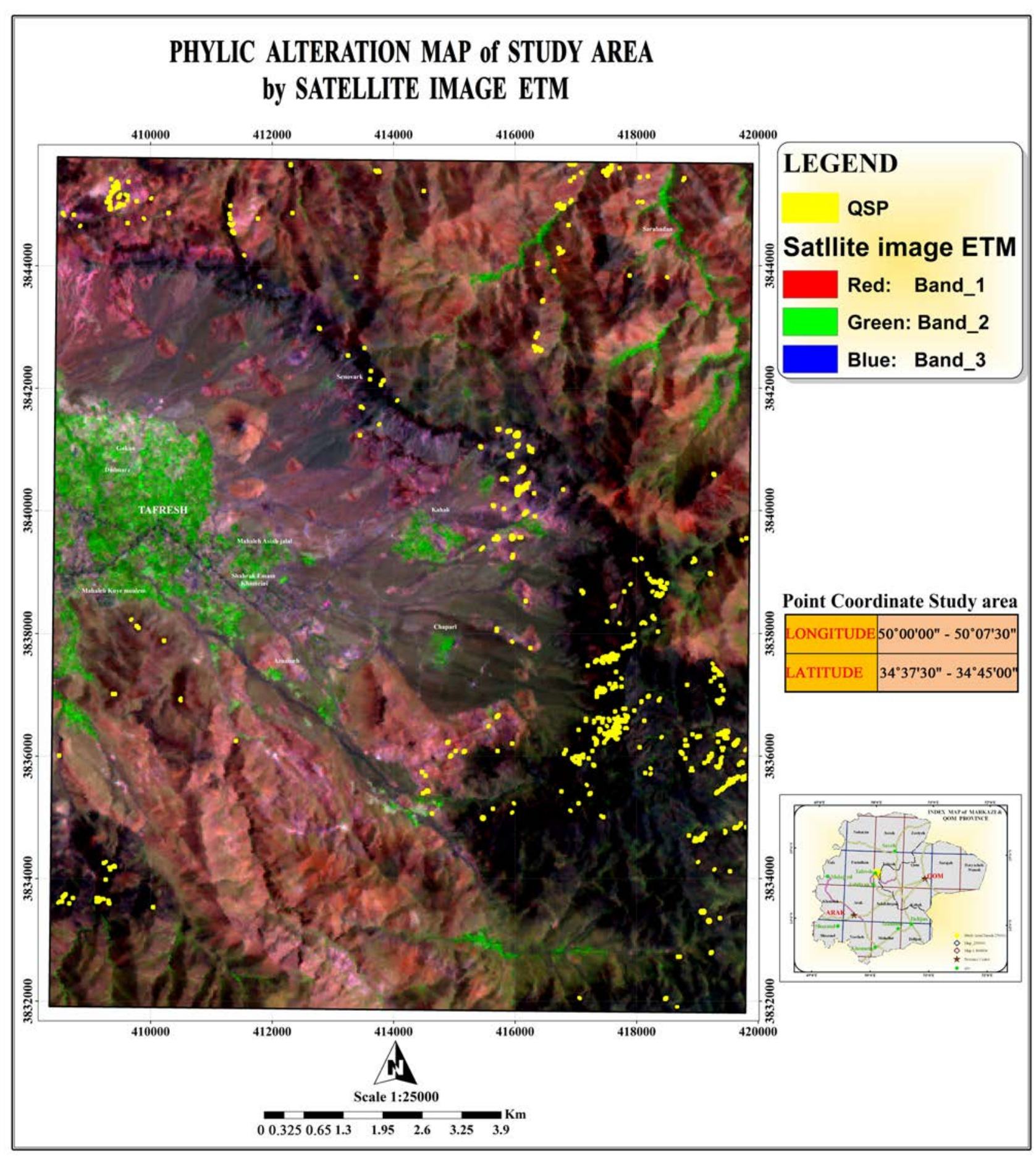

Figure 21. Sericitic alterations [15].

Beside, most of the thickness dykes in Tafresh were formed along Strike Slip faults at direction Northeast-Southwest (Figure 25). Most of the time, operations of these faults caused that some of dykes can be risen in Tafresh and producing lots of alteration zones and mineralization.

Thrust faults are most significant faults of this area that caused rock units were slipped and overturned on each other and outcrops of ancient rock units are demonstrated in the Tafresh (Figure 24). Sometimes, these faults led intrusive massive and dykes at this area (Figure 25). 


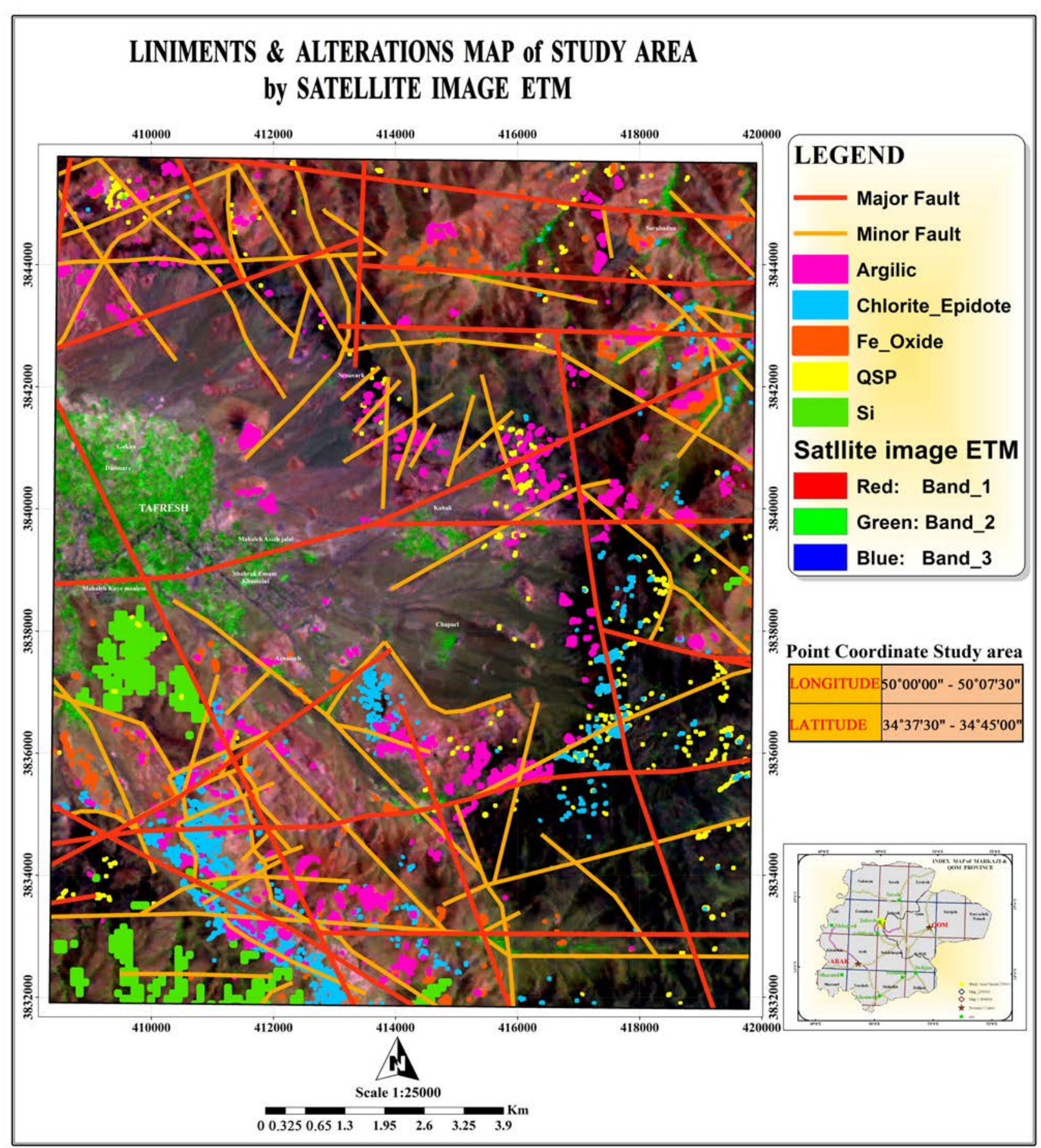

Figure 22. Map of incorporating alterations and Liniments at study area scale 1:25,000 [15].

\section{Geochemical and Heavy Minerals Studies}

Goal of geochemical investigations is finding zones of ore deposit potentials as Non Element deposits and Element deposits. In these studies, next to the preparing of samples, XRF analysis was fulfilled for measuring some elements like $\mathrm{Cu}, \mathrm{Zn}, \mathrm{Pb}, \mathrm{Cr}, \mathrm{Ni}, \mathrm{Sn}, \mathrm{As}$, and $\mathrm{Bi}$. Eventually, 13 anomalous elements were distinguished at boundary of Tafresh Map such as $\mathrm{Ag}, \mathrm{As}, \mathrm{Ba}, \mathrm{Bi}, \mathrm{Cd}, \mathrm{Cu}, \mathrm{Pb}, \mathrm{Hg}, \mathrm{Ni}, \mathrm{Sn}, \mathrm{V}, \mathrm{W}$, and $\mathrm{Zn}$. In the geochemical studies, 47 geochemical samples and 17 heavy mineral samples were picked up and studies (Figure 26). 


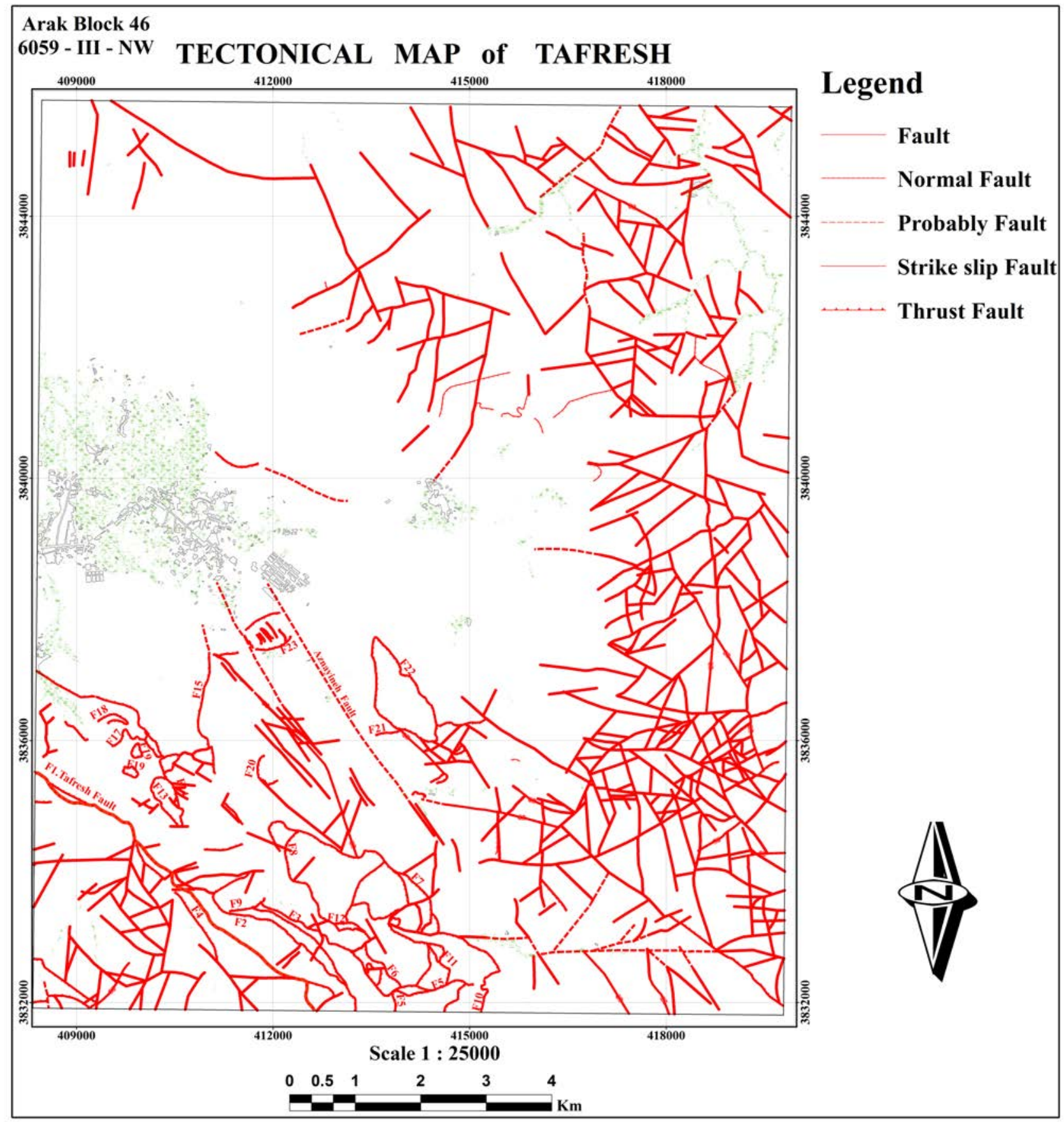

Figure 23. Structural map of Tafresh.

According to Table 1 that showed results of geochemical analyses of two samples of intrusive mass, and 10 samples of dykes of study area. As matter of fact, geochemical data showed that the East of area has low anomalies of $\mathrm{Ag}$ as well as $\mathrm{Sn}$ and Bi that host rock is sedimentary limestone, tuff, sandstone, and shale, whereas; anomalous area of $\mathrm{Pb}, \mathrm{Bi}, \mathrm{Hg}, \mathrm{Cr}$, $\mathrm{Sb}$ had been found at Western North of study area which related to Dacite, Riodacite, Limestone, and Marl.

As to Figure 26 that was resulted from incorporating of geochemical anomalous areas, most of the anomalous areas of elements were located at Sought, Southwest, Southeast, and North parts of study area. As case in point, most of anomalous areas of $\mathrm{Ag}, \mathrm{V}, \mathrm{Sn}, \mathrm{Pb}, \mathrm{Ni}, \mathrm{BA}$, and As elements are coincided at Southwest of study area. 


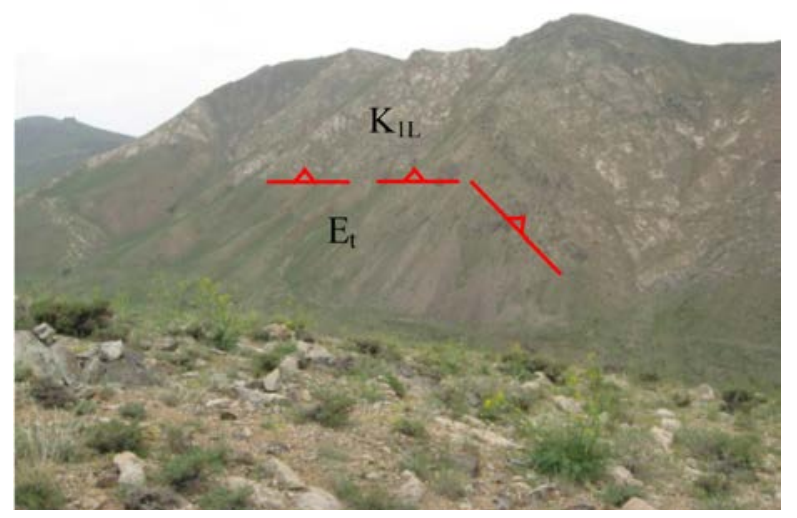

Figure 24. View of thrust fault that caused cretaceous rocks overturned on the Eocene rock units (Tuff).

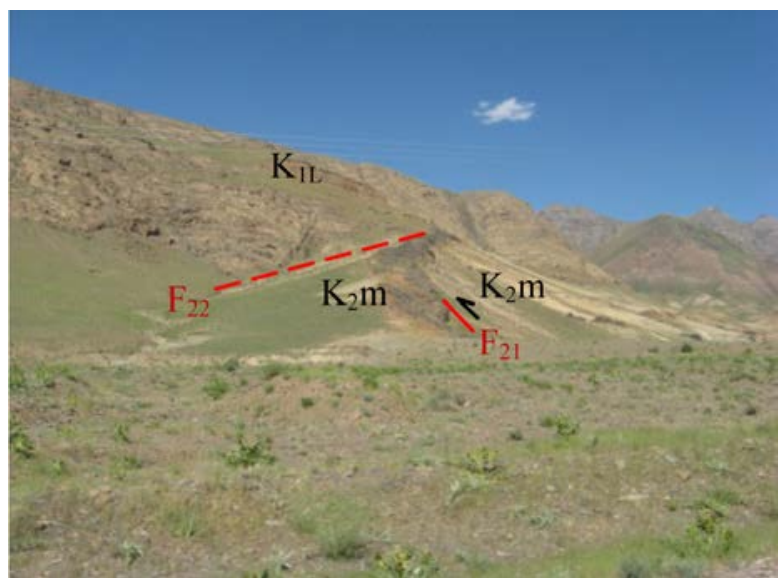

Figure 25. location of intersection of two faults and outcrop of Andesite dyke in Tafresh.

Table 1. Results of geochemical analysis related to several intrusive massive and dykes in tafresh area and along with average of elements at volcanic rocks (Red value is associated with abnormal amount of elements).

\begin{tabular}{|c|c|c|c|c|c|c|c|c|c|c|c|c|c|c|c|}
\hline \multirow{2}{*}{ Name of Rock } & \multicolumn{15}{|c|}{ Results of geochemical analysis related to several intrusive massive and dykes in Tafresh } \\
\hline & Sample Number & $\mathrm{Au}$ & $\mathrm{Fe}$ & $\mathrm{Ag}$ & As & $\mathrm{Bi}$ & $\mathrm{Cd}$ & $\mathrm{Cu}$ & Mo & $\mathrm{Pb}$ & $\mathrm{S}$ & $\mathrm{Sb}$ & $\mathrm{V}$ & $\mathrm{W}$ & $\mathrm{Zn}$ \\
\hline Dyke & SD077GI & 3 & 36,073 & 0.3 & 7.4 & 0.21 & 0.31 & 30 & 0.9 & 19 & 6537 & 0.6 & 120 & 1.1 & 48 \\
\hline Dyke & SD161GI & 147 & 30,008 & 0.42 & 7.8 & 0.25 & 0.23 & 35 & 0.85 & 21 & 270 & 0.61 & 23 & 1.3 & 17 \\
\hline Diorite & TF231GI & 6 & 15,419 & 0.26 & 7.8 & 0.22 & 0.28 & 64 & 1.21 & 19 & 293 & 0.61 & 80 & 1.56 & 38 \\
\hline Diorite & TF129GI & 1 & 21,957 & 0.31 & 7.7 & 0.25 & 0.27 & 23 & 1.07 & 20 & 115 & 0.65 & 46 & 1.51 & 39 \\
\hline Dyke & TF223GI & 6 & 16,202 & 0.25 & 7.6 & 0.26 & 0.26 & 23 & 0.84 & 62 & 1018 & 0.59 & 36 & 1.08 & 43 \\
\hline Dyke & TF152GI & 3 & 38,007 & 0.34 & 8 & 0.35 & 0.28 & 9 & 1.09 & 23 & 344 & 0.64 & 78 & 1.51 & 79 \\
\hline Gabbro Dyke & TF175GI & $<$ & 73,990 & 0.28 & 7.2 & 0.41 & 0.26 & 125 & 0.63 & 24 & 194 & 0.57 & 166 & 1.04 & 117 \\
\hline Gabbro Dyke & TF177GI & 7 & 315,499 & 0.63 & 460.5 & 55.28 & 0.28 & 381 & 0.67 & 90 & 731 & 14.6 & 48 & 1.12 & 209 \\
\hline Gabbro Dyke & TF178GI & 91 & 335,355 & 0.34 & 223.9 & 44.91 & 0.25 & 220 & 0.71 & 119 & 546 & 0.7 & 55 & 1.69 & 263 \\
\hline Dyke & TF315GI & 112 & 69,829 & 6.21 & 411 & 0.4 & 57 & 79 & 1.1 & 14809 & 735 & 1.7 & 118 & 21.34 & 4678 \\
\hline Gabbro Dyke & TF179GI & 5 & 230,107 & 4.89 & 611.3 & 24.33 & 0.3 & 811 & 1.43 & 282 & 1364 & 23 & 71 & 1.69 & 127 \\
\hline Gabbro Dyke & TF183GI & $<$ & 52,528 & 0.31 & 7.8 & 0.34 & 0.28 & 34 & 0.74 & 23 & 2205 & 0.59 & 162 & 1.25 & 70 \\
\hline $\begin{array}{c}\text { Average of Volcanic } \\
\text { Rocks }\end{array}$ & - & 1 & 50,000 & 0.07 & 1.8 & 425 & 0.1 & 55 & 1.5 & 50 & 1050 & 0.2 & - & 1.5 & 70 \\
\hline
\end{tabular}




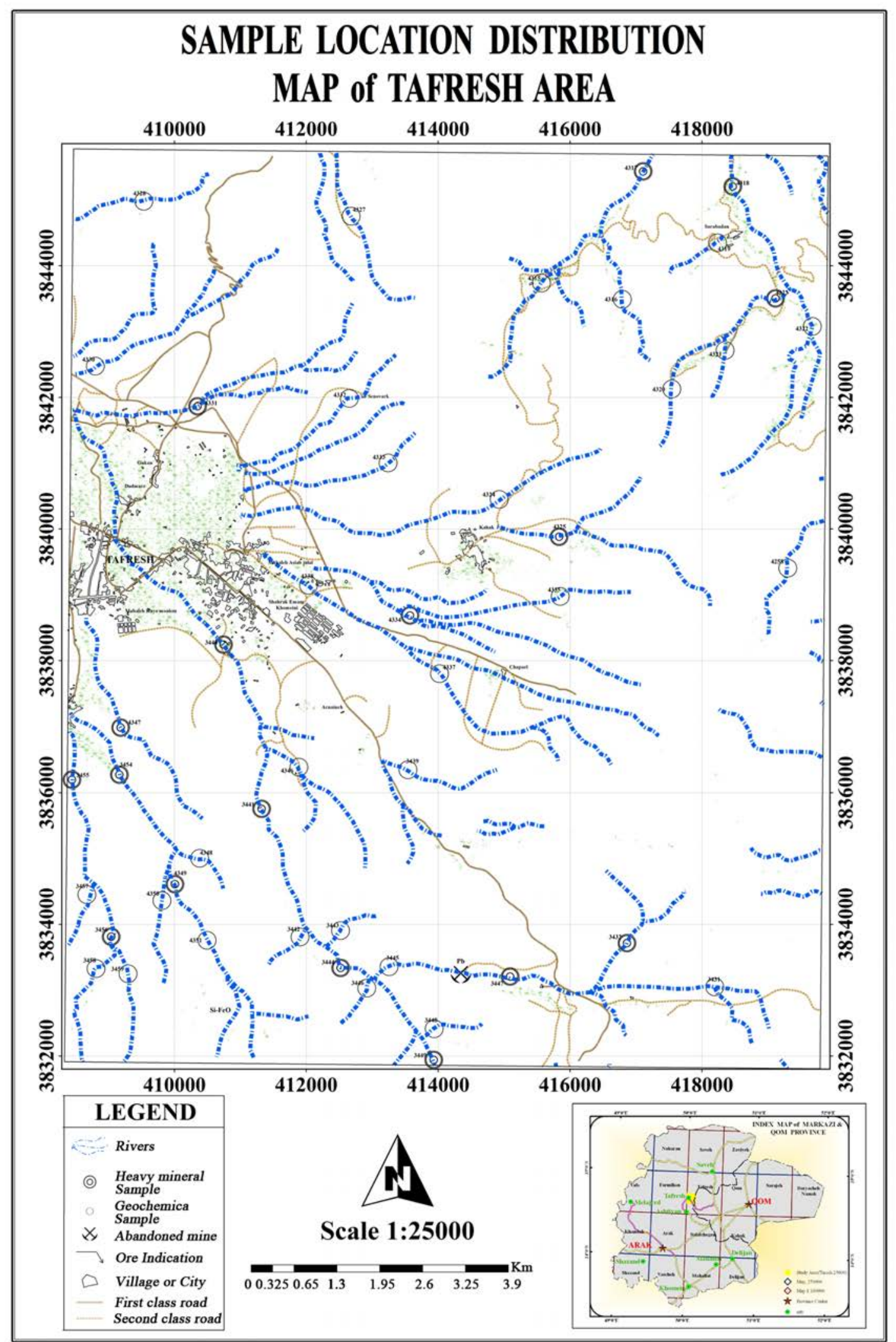

Figure 26. Location of geochemical samples and heavy mineral samples in Tafresh map scale 1:25,000. 
Alongside that some anomalous areas of $\mathrm{Bi}, \mathrm{Cd}, \mathrm{V}, \mathrm{Cu}$, and Ba elements were located at Sought part of Tafresh. Also, anomalous areas of $\mathrm{Bi}, \mathrm{Sn}, \mathrm{W}, \mathrm{Zn}$ elements can be observed at Northwest parts and anomalous parts of V, $\mathrm{Bi}$, and $\mathrm{Cd}$ were found at Southwest of study area as well (Figure 26).

Heavy mineral study is another significant and practical method for investigating and identifying potential areas of ore deposits at regional exploration. As a monumental point in heavy mineral studies at Tafresh is most of anomalous areas that were resulted from heavy mineral studies were coincided with anomalous areas of geochemical studies (Figure 27 and Figure 28). The objective assessment maps of element amount of Tafresh area were provided bas on analyzing and processing of geochemical data that had been accomplished on the provided samples. These maps showed separation and rate of $\mathrm{Cu}, \mathrm{Mo}, \mathrm{Pb}, \mathrm{Zn}, \mathrm{Fe}$, and $\mathrm{Mn}$ elements, and with regard to these maps, $\mathrm{Cu}$ element had most amount at Southeast than Northeast in Tafresh Map scale 1:25,000, whereas

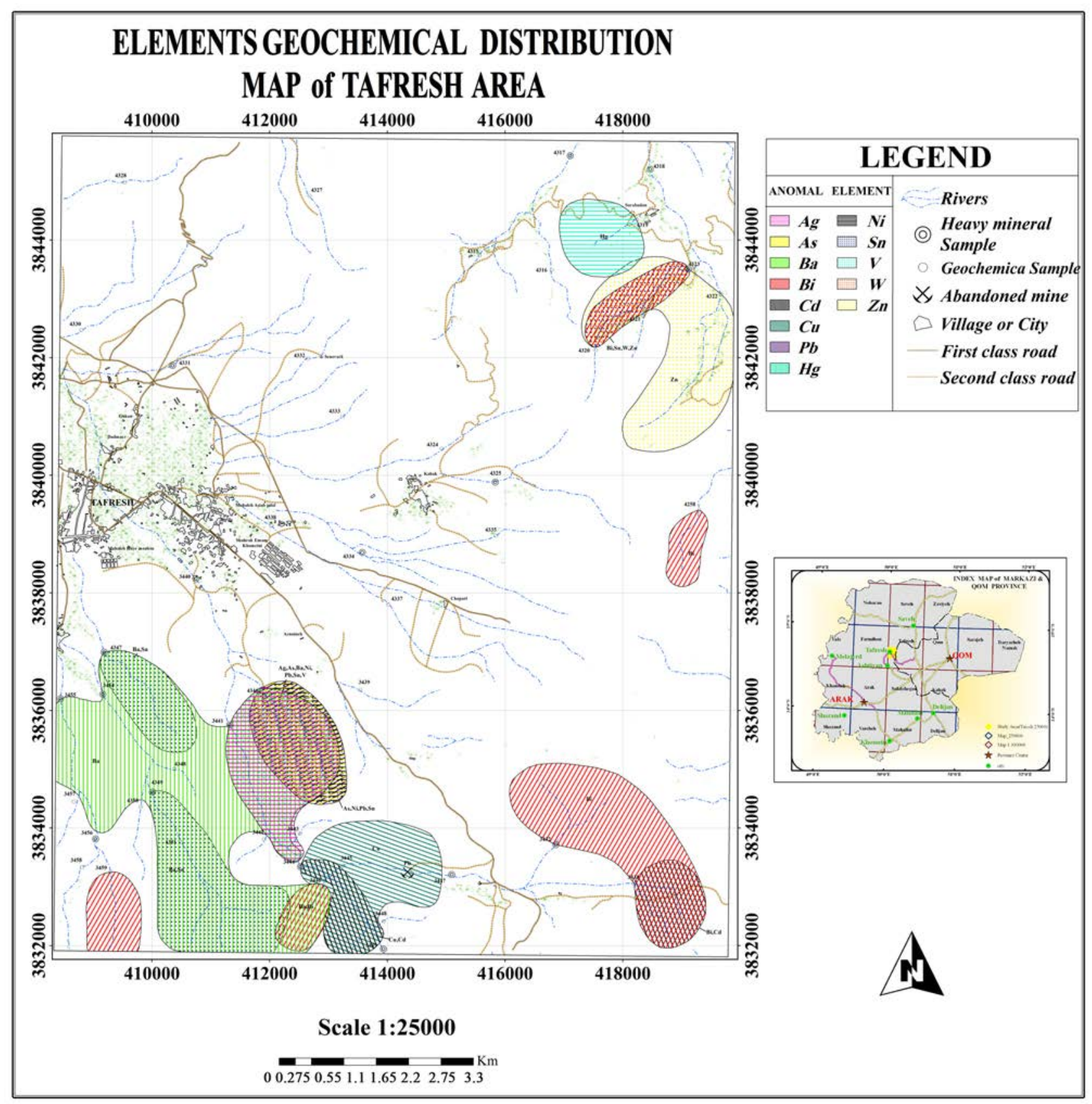

Figure 27. Map of geochemical abnormalities at Tafresh sheet scale 1:25,000. 
Zn element had most amount at Northeast of area.

As result of geochemical and heavy mineral studies, two promising areas, according to precedence, were introduced in Tafresh area.

First area had involved mineralization of $\mathrm{Cu}, \mathrm{Cd}, \mathrm{Zn}, \mathrm{Bi}, \mathrm{V}, \mathrm{Pb}, \mathrm{Ni}, \mathrm{As}, \mathrm{Ag}, \mathrm{Sn}$, and $\mathrm{Ba}$ elements at South of Tafresh. Secondary area included boundaries of $\mathrm{Hg}, \mathrm{Pb}, \mathrm{Zn}, \mathrm{W}, \mathrm{Sn}$, and Bi elements at Northeast of Tafresh.

Both of identified potential areas have remarkable adaptation with location of intrusive massive, alteration zones, and normal and Thrust faults of study area which it indicate appropriate relationships between intrusive massive of Tafresh with forming ore deposits (Figure 29).

According to analyses of dykes and intrusive massive at Tafresh, we could conclude that dykes and intrusive massive of Tafresh are enriched from these elements such as $\mathrm{Au}, \mathrm{Ag}, \mathrm{Sulfur}, \mathrm{Cu}, \mathrm{Pb}, \mathrm{Zn}, \mathrm{W}$, and $\mathrm{As}$, and caused

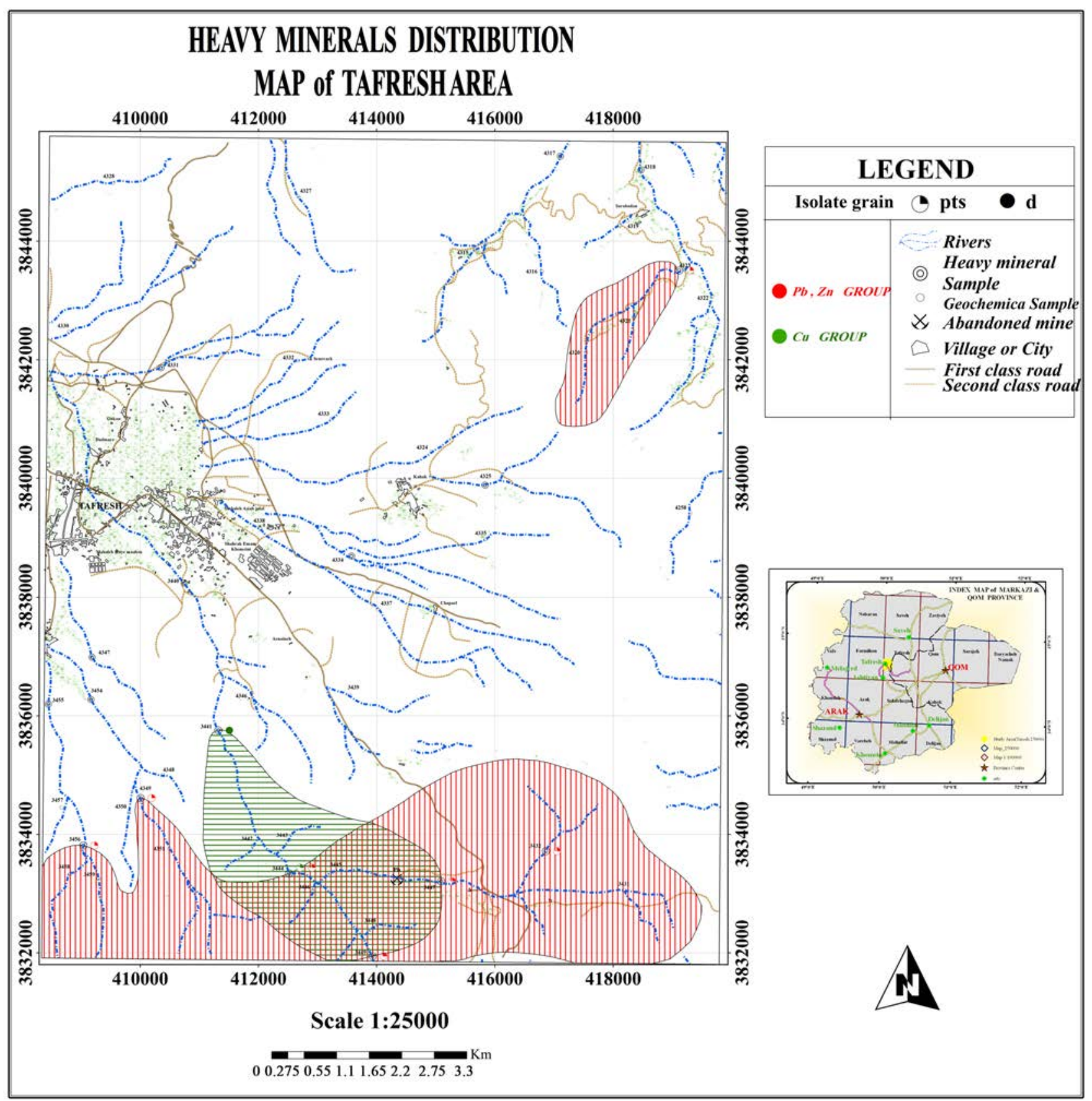

Figure 28. Map of heavy mineral abnormalities at Tafresh sheet scale 1:25,000. 
that mineralization has been formed as Skarn and Hydrothermal deposits in contact with limestone rocks. As witness, we can imply to Siliceous alterations and veins that were produced by operation of hydrothermal fluids. Alavi Naeeni and et al., (1381) had indicated to mineralization of $\mathrm{Pb}, \mathrm{Ba}, \mathrm{Cu}, \mathrm{Fe}$, and $\mathrm{Mn}$ elements and mineralization potential of $\mathrm{Cu}$ and Au porphyry in Tafresh at Geochemical Map of Tafresh with scale 1:100,000.

\section{Mineralization}

Most of dominate mineralization of study area is Pyrite, Chalcopyrite, Pyrrhotite, Magnetite, Hematite, Goethite, Ilmenite, and Galena that were observed by studying thin sections. It is noteworthy that most of these minerali

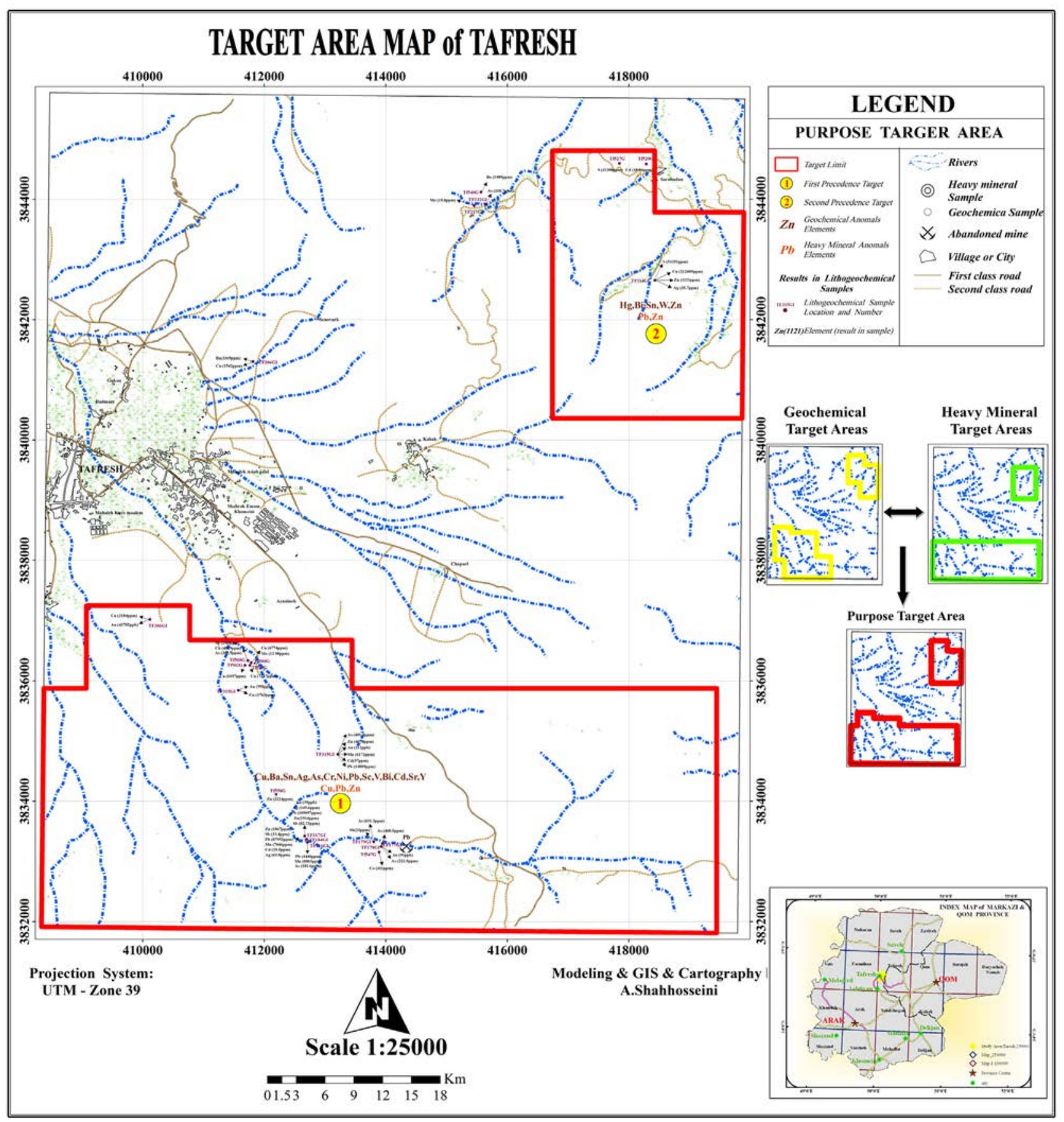

Figure 29. Map of promising area and litho-geochemical sampling in Tafresh sheet scale 1:25,000. 
zation are associated with Granodiorite intrusive massive of Sarabadan at Northeast of this area that they can be observed as Siliceous vein and Veinlets which had mineralization (Figure 30). Meanwhile, Mineralization of Pyrite, Goethite, Hematite, and Galena were deposited at Southwest of Tafresh city (Figure 31). Base on studies of Alavi Naeeni and his colleagues (1381) existing of $\mathrm{Cu}, \mathrm{Ba}, \mathrm{Fe}$, and $\mathrm{Mn}$ minerals can confirm mineralization potential of $\mathrm{Cu}$ and $\mathrm{Au}$ of porphyry type. Also, existing of Chlorite, Sericite, and Carbonate are principal factors for existing Carbonate, Sericitic, and Chlorite alterations at study area and most of which are related to Granodiorite dykes. It is noteworthy that dominate alterations are related to siliceous dykes that they were penetrated into the Carbonate units as vein. Depend on existing evidences, mineralization of these dykes encompass Iron Oxide, Copper Sulfide, and Copper Carbonate like Malachite. Also, Oligocene intrusive massive with Granodiorite composition and penetrated intrusive volcanic rocks made deposits of Epidote, Quartz, and Hornfels minerals
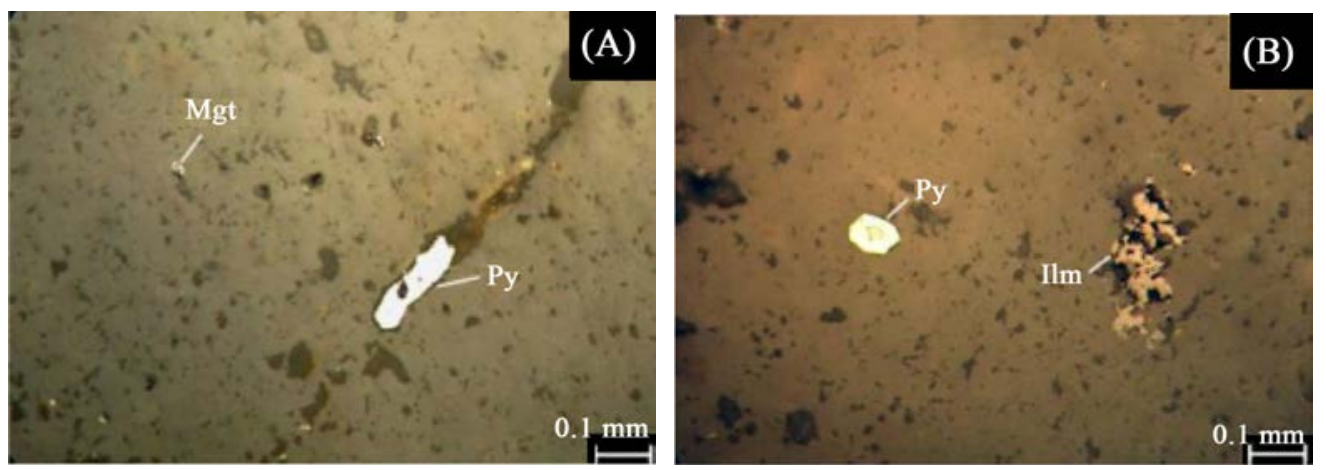

Figure 30. (A) Pyrite veinlets into the context (much tiny Magnetite crystal into the context). (B) Magnetite beside euhedral and almost large crystals of Pyrite.
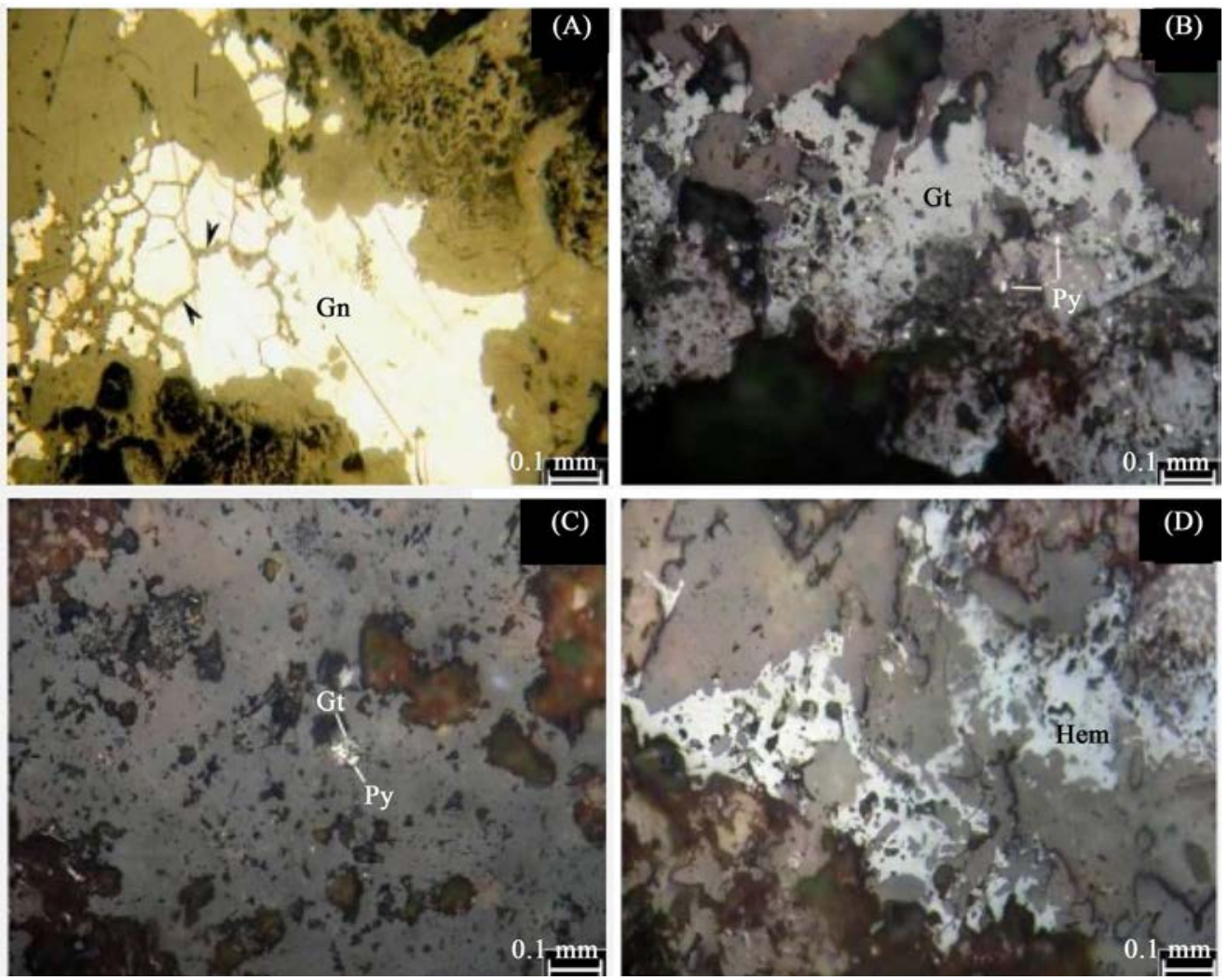

Figure 31. (A) Galena veinlets that were become partly breccias as well as it was oxidized from margins to sericite along fractures. (B) Concentration of goethite minerals at texture that involved remains of primary crystals of pyrite. (C) Scattered crystals of pyrite that was oxidized to goethite as partly. (D) Secondary hematite crystals at texture. 
into the Andesite and Tuffaceous rocks.

\section{Promising Areas of Ore Deposits at Tafresh}

With regard to geological conditions, type of possible deposits, mineralization pattern, and type of mineralization of Markazi Province, initially, agents of mineralization's controllers were utilized at exploration models (Exploration types) for probing and distinguishing promising areas of ore deposits that involved intrusive massive, origin of mineralization, type of rock units and host rocks [12]. As such, appropriate environment for each mineralization was separated base of geological map. Following that all data and layers were incorporated depend on effective processes at mineralization, geochemical indications, procedure of effective local and regional structures, and alterations had been processed from satellite images. It should be noticed that each of factors had been incorporated base on one specific significant ratio related to each type of mineralization. By the way, all steps of processing data, incorporating various layers, and producing each of models were fulfilled by GIS software. According to the incorporated maps of suggested models, the area of Tafresh can be prone to potential of $\mathrm{Au}, \mathrm{Cu}$, $\mathrm{Ag}, \mathrm{Hg}, \mathrm{Mn}, \mathrm{Pb}, \mathrm{Zn}$, and Fe elements, $\mathrm{Sb}$ metalloid, and non-element of Ba.

With regard to data incorporating, 19 types of possible ore deposit models were investigated at Tafresh area that most important and possible of them is in the following models:

\subsection{Model of Cu Porphyry}

Most possible type of mineralization in Tafresh (Figure 32).

Host Rocks: Granodiorite to Tonalite, Quartz Monzodiorite, diorite or Syenite.

Tectonic: Local and regional faults.

Tectonic Condition: tectonic location along with volcanism.

Age: Mesozoic and Cenozoic.

Alterations: Sericitic, Argillic, Propylitic.

Geochemical characteristics: $\mathrm{Sn}, \mathrm{Cu}, \mathrm{Ag}, \mathrm{W}, \mathrm{Pb}, \mathrm{Zn}$, and Bi.

\subsection{Model of Cu-Mo Porphyry}

Host Rocks: Tonalite to Monzonity (Figure 33).

Tectonic: Local and regional faults.

Texture: Stockwork, Veinlets, and Porphyry (Molybdenite and Chalcopyrite minerals into the vein and veinlets and near to intrusive massive).

Alterations: Propylitic.

Geochemical characteristics: $\mathrm{As}, \mathrm{Cu}, \mathrm{Ag}, \mathrm{W}, \mathrm{Pb}$, and $\mathrm{Zn}$.

\subsection{Mode of Substituted Polymetallic}

Host Rocks: sedimentary rocks like Limestine, Dolomite, and sometimes shale that were interrupted by porphyry massive (Figure 34).

Tectonic: Local and regional faults.

Alterations: Siliceous and Propylitic.

Geochemical characteristics: W, Ag, $\mathrm{Cu}, \mathrm{As}, \mathrm{Bi}, \mathrm{Zn}, \mathrm{Pb}$, and $\mathrm{Ba}$.

\subsection{Model of Chloride Epithermal Gold deposit}

Host Rocks: Andesite, Dacite, Riodacite, Riolite, as well as sedimentary rocks along with them (Figure 35).

According to the afore noted, concentration of areas prone to elements and non-elements potential which were distinguished at Tafresh, in order to preferences ,is four exploratory targets, 1, 2, 3, and 4 that would be introduced. Meanwhile, exploratory samples of each of these mentioned targets verified the potential of them (Figure 36).

First exploratory target is located at South and Southwest of Tafresh. This target is most significant area in our study area that had high concentration of fundamental elements with remarkable rate that occasionally some of these elements were affordable such as $\mathrm{Au}$ (958 ppb), $\mathrm{Cu}$ (6774 ppm), $\mathrm{Pb}$ (14,809 ppm), $\mathrm{Zn}$ (4678 ppm), and $\mathrm{Ag}, \mathrm{Sb}, \mathrm{As}$, and W. Basic dykes with Gabbrodiorite composition and Siliceous veins along with Siliceous, Ar- 
gillic, and Propylytic alterations were most important and impressive agents in this target with high potential of ore deposits (Figure 37).

Second exploratory target is identified at North and Northeast of Tafresh area that have high rate of concentration of mineralization such as $\mathrm{Cu}(212,609 \mathrm{ppm}), \mathrm{Zn}(523 \mathrm{ppm})$, Mo (15/85 ppm), and $\mathrm{Au}, \mathrm{Ag}, \mathrm{Hg}$, Sb, and Fe elements. On the face of it, most of this mineralization had been done via penetrating Dacite, Tonalite, and Quartzdiorite intrusive massive as well as Dioritic, Gabbro, Andesitic dykes. Meanwhile, Hydrothermal mineralization with high rate of copper deposits were concentrated on this target by these intrusive massive and dykes (Figure 38).

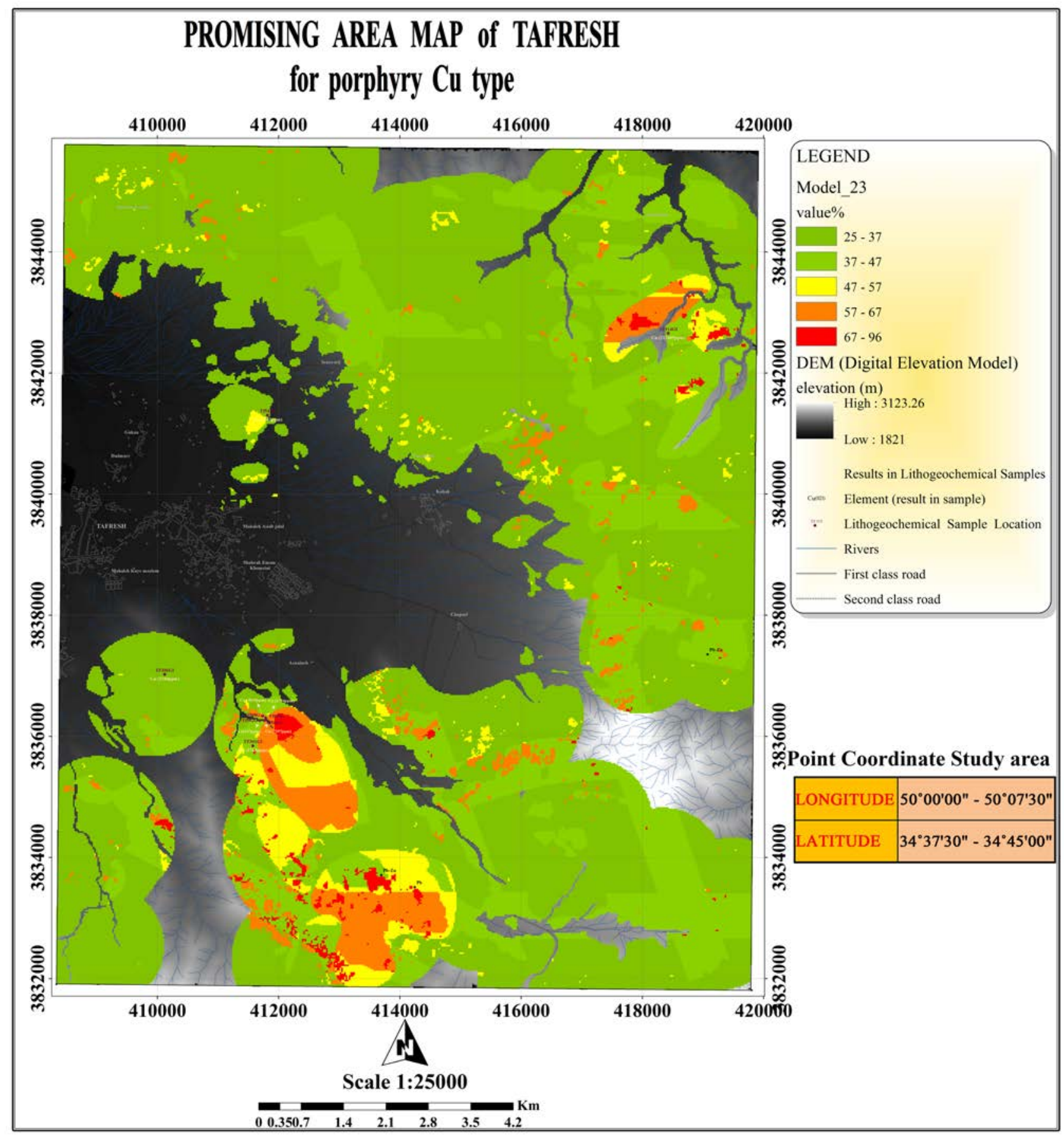

Figure 32. Map of cu porphyry model in Tafresh sheet scale 1:25,000. 


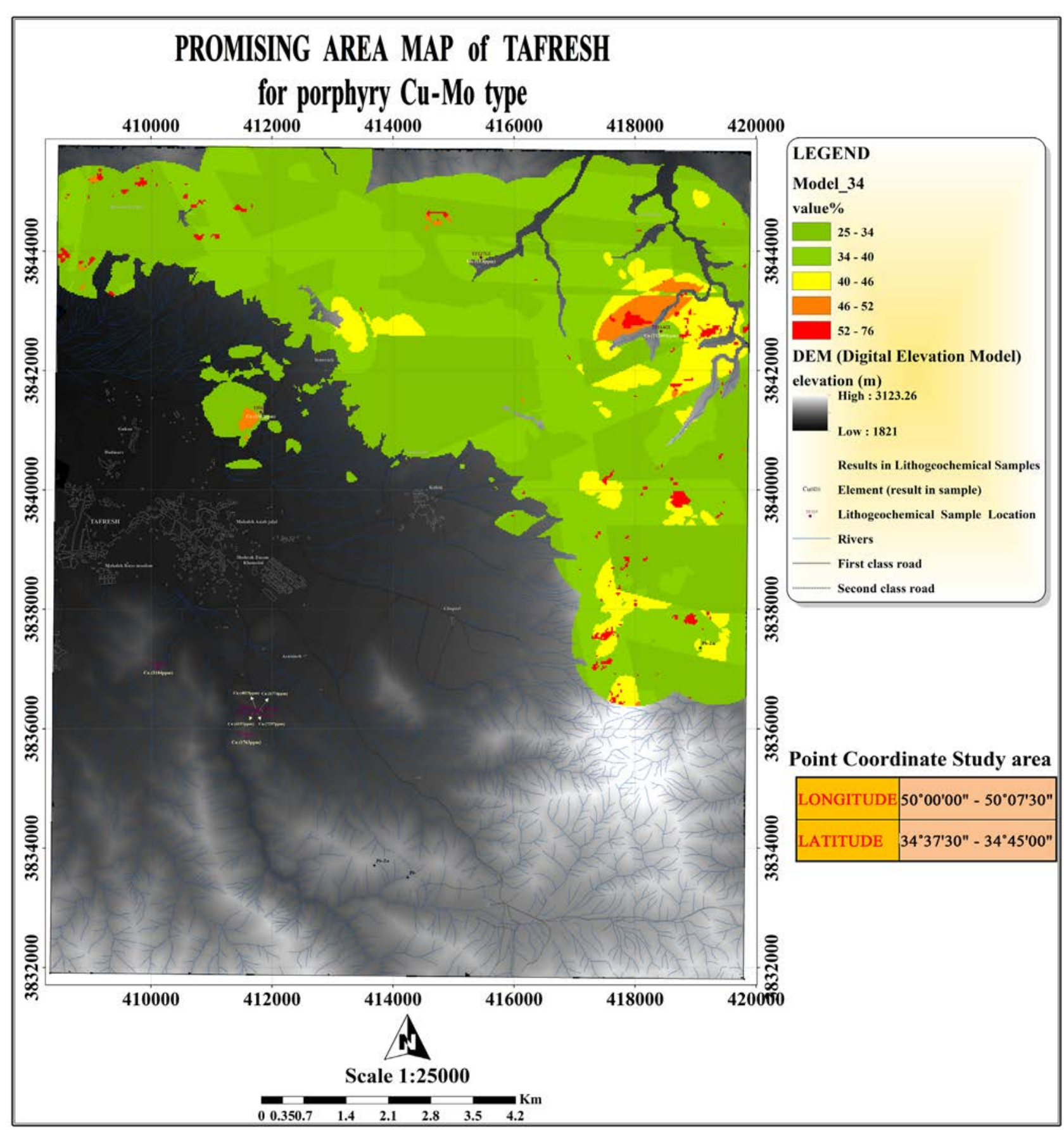

Figure 33. Map of cu-mo porphyry model in Tafresh sheet scale 1:25,000.

Third exploratory target that was located at Eastern of Tafresh, and concentration of mineralization of $\mathrm{Fe}$ and Sb elements had been seen which with regard to expansion and scattering of intrusive massive's areas and effective alterations at Tafresh, this target cannot be considered for exploratory operations.

Also, fourth exploratory target was located at Weastern of Tafresh sheet that had mineralization effects of $\mathrm{Cu}$, $\mathrm{Sb}$, and Fe elements.

\section{Conclusions}

Tafresh area has high rate of mineralization with remarkable and high concentration of various kind of alterations 


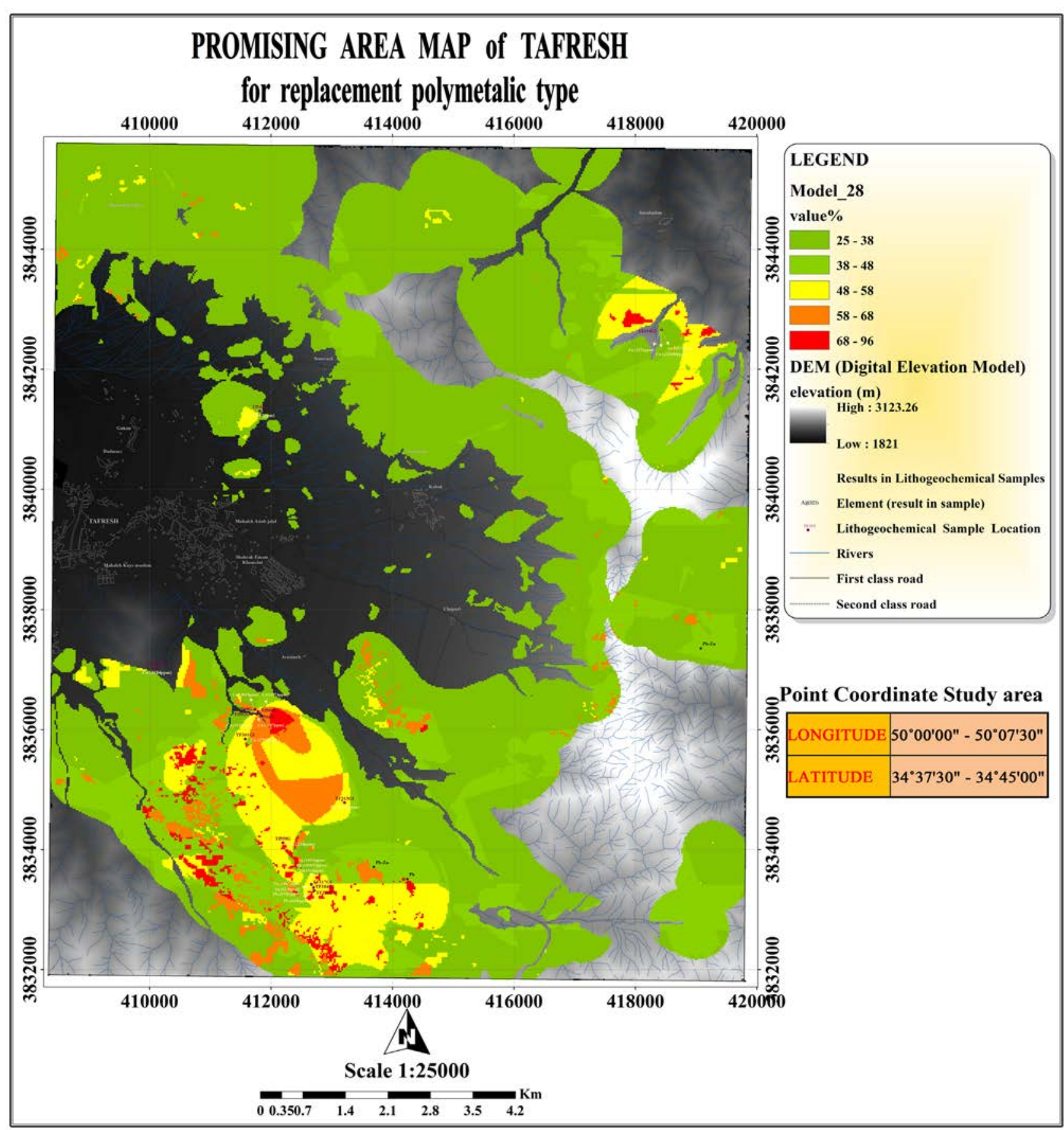

Figure 34. Map of chloride epithermal gold deposit model in Tafresh sheet scale 1:25,000.

which had been produced by its specific location and effective and varied kinds of agents such as locating on the Urumieh-Dokhtar zone, operating diverse types of tectonic energies, penetrating intrusive massive and forming those on the area, affecting thrust and normal faults that were related with compressible motions due to impact of Arabian and Eurasia plates. Most of volcanic massive had been resulted of subduction of Arabian's intrusive plate that remains of oceanic crust were still preserved. Also, lots of faults collections had been formed via making faults by penetrating plutonic massive and motions of regional tectonics. Depend on field evidences, processing satellite images, analyzing and incorporating all of data, most of the mineralization were taken place at sedimentary rocks of Cretaceous that involved Limestone and Shale. To be precise, most of this mineralization 


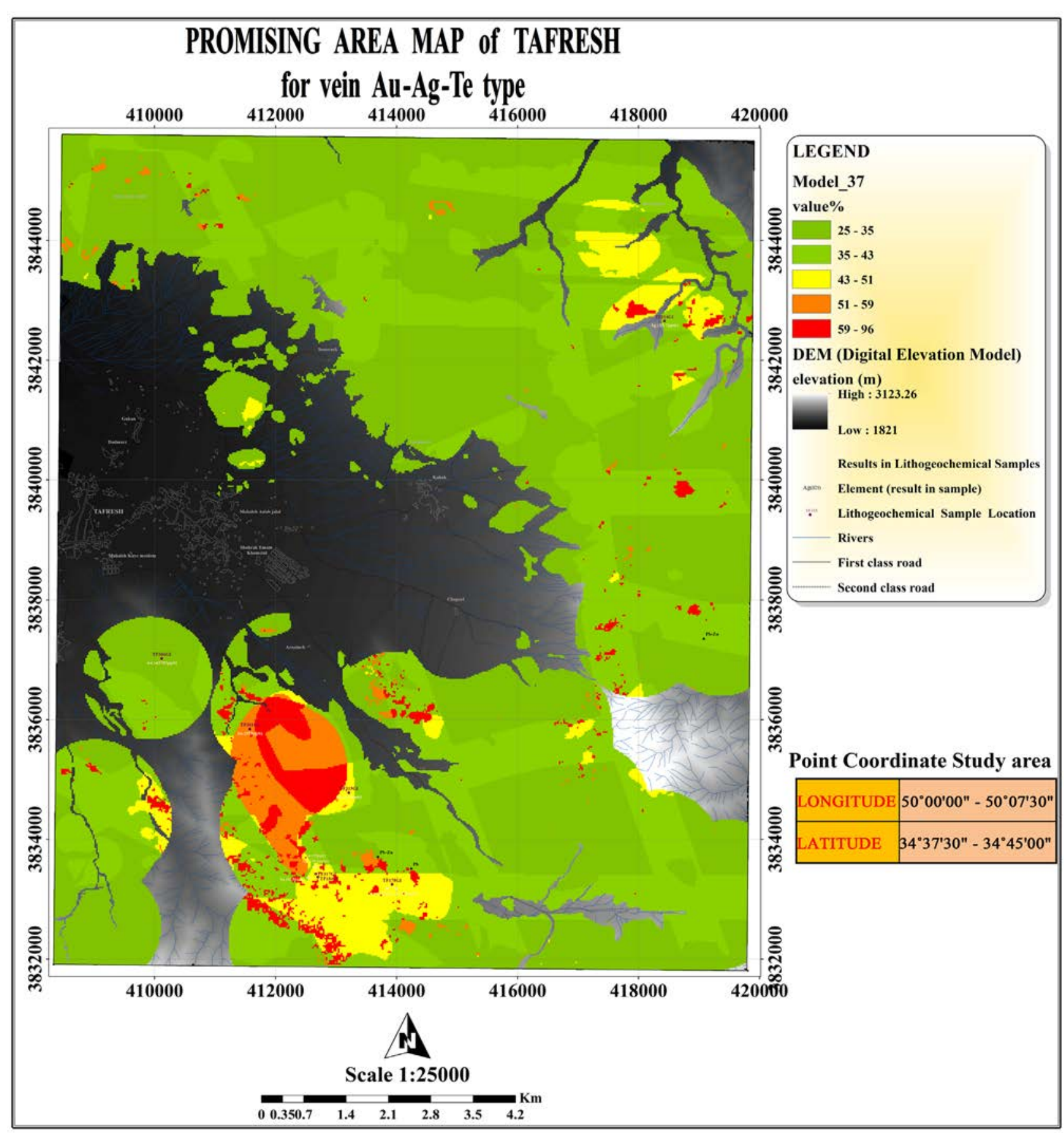

Figure 35. Map of chloride epithermal gold deposit model in Tafresh sheet scale 1:25,000.

followed up from procedure of major and deep faults that whereby the hydrothermal solution could influence various kinds of area rocks. So, this issue is obvious reason for mutual effect of faults and intrusive massive on this area.

Base on the processing satellite images and surveying witnesses of field, two kinds of major alterations were identifies in boundary of Tafresh. First group was resulted from supergene processes that don't have so much importance for elemental mineralization in terms of economic situation. Another kind of alterations were androgenic that are so remarkable for elemental mineralization. For instance, Siliceous alteration was one of the most effective alteration in this area and with regard to relation of these alterations with volcanic and tuffaceous 


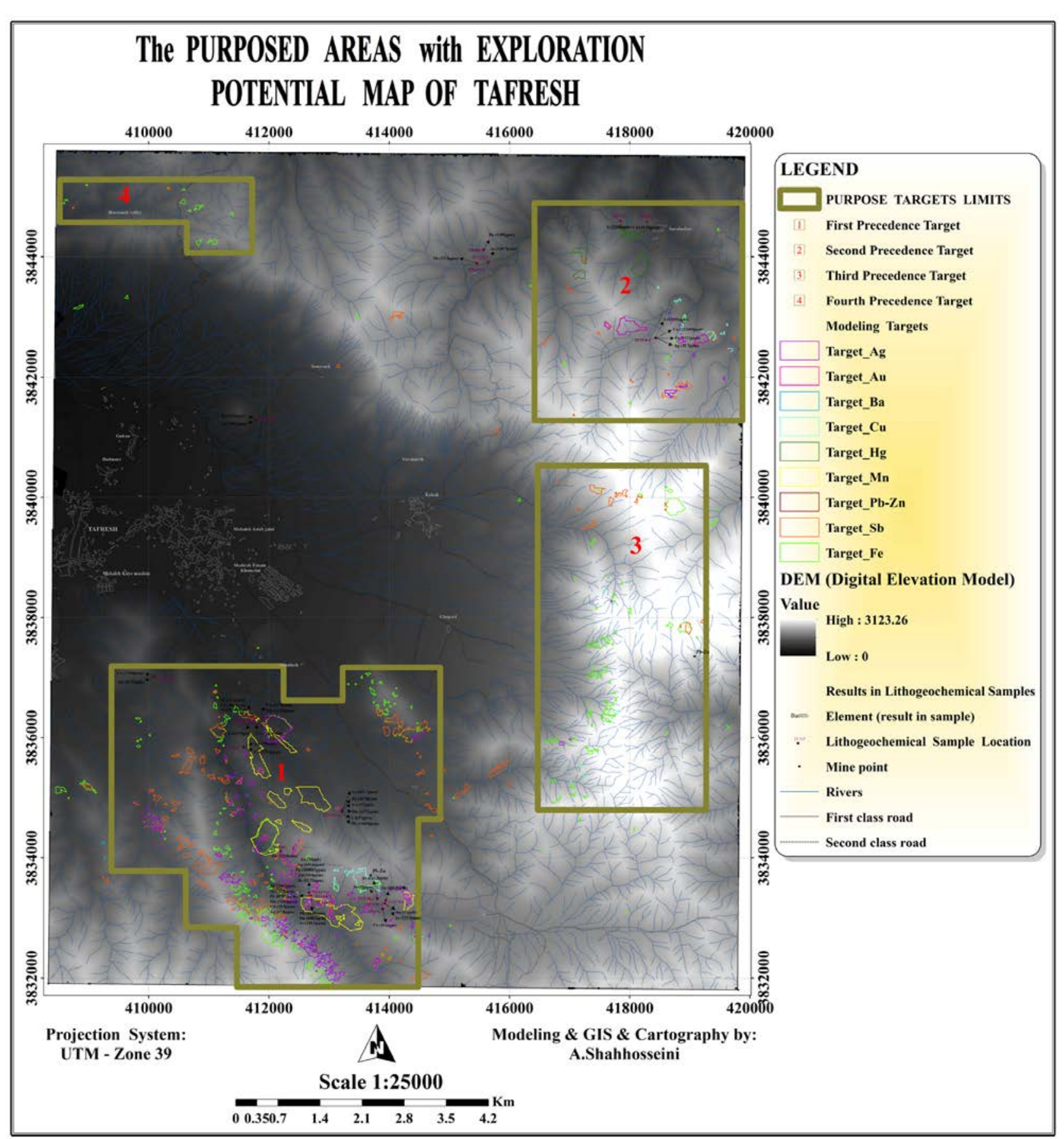

Figure 36. Suggested exploratory targets at Tafresh sheet scale 1:25,000.

rocks, origin of these alterations has been Hydrothermal operations along with intrusive massive. Sometimes, these alterations could go up on the surface of earth by some of dykes and faults. Also, Kaolinite alterations and Iron Oxide of Tafresh area were related to acidic tuffaceous units of Eocene. Kaolinite alteration had been extended as widespread in boundary of Tafresh. However, this alteration is apparently related to Supergene process and endogenic processes have not had so many roles at producing these alterations. So, remarkable elemental mineralization cannot be observed at these alterations. These alterations can be considerable just as extracting Kaolinite. Also, we can see several numbers of siliceous veins in study area which were situated at fractures and breaks. Above all, importance of dykes can be proved by observing some siliceous veins that penetrating 


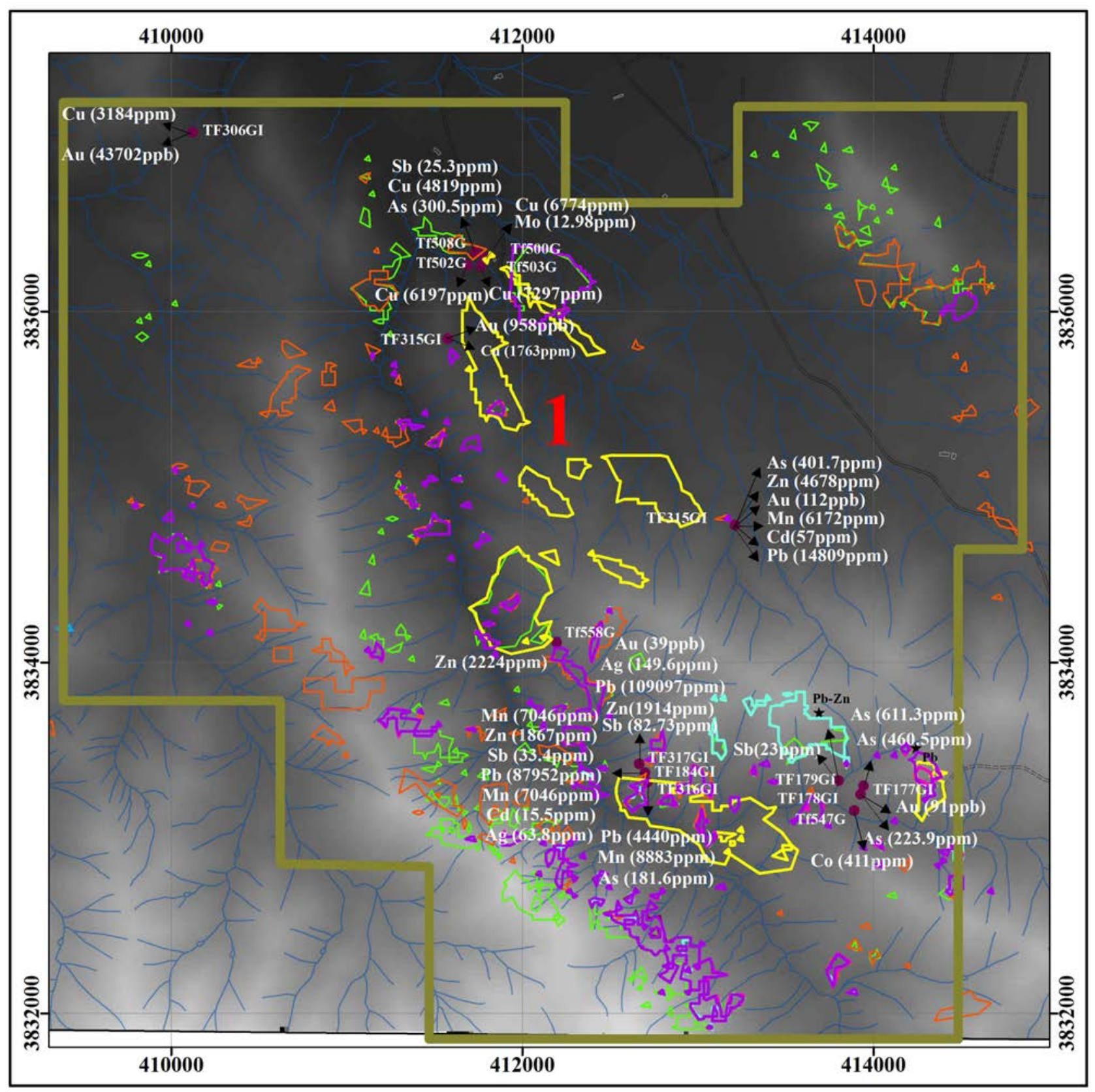

Figure 37. First exploratory target is most important exploratory area at study area. This target had high potential of ore deposits for exploration such as $\mathrm{Au}, \mathrm{Cu}, \mathrm{Pb}, \mathrm{Zn}, \mathrm{Ag}, \mathrm{Sb}, \mathrm{As}$, and $\mathrm{W}$.

into the limestone rocks without existing intrusive massive.

Another thing worth adding that is dykes, which were most fundamental agent for mineralization at Tafresh area because some remarkable reasons such as sedimentary rocks that are dominate lithology of area, Basic dykes, Siliceous veins, and as well as high rate of concentration of $\mathrm{Cu}$ and $\mathrm{Au}$ elements near to dykes. Hence, we can assert base one existing witnesses that Tafresh has remarkable concentration of $\mathrm{Cu}$ and $\mathrm{Au}$ mineralization. It goes without saying that dominate mineralization at study area is kind of Skarn and Hydrotermal. So, we are able to claim origin of this mineralization can be associated with intrusive massive, volcanic operations, dykes, and fluids flowing from intrusive massive and dykes. It is assured that kinds of Tafresh's ore deposits were related to dykes and intrusive massive at this area such as ore deposits are associated with forming reserves of $\mathrm{Cu}$ porphyry like Skarn $(\mathrm{Cu}, \mathrm{Fe}, \mathrm{Au}, \mathrm{Zn})$, Polymetalic Replacement ( $\mathrm{Ag}, \mathrm{Pb}, \mathrm{Zn}, \mathrm{Cu}, \mathrm{Au})$, Distal Disseminated 


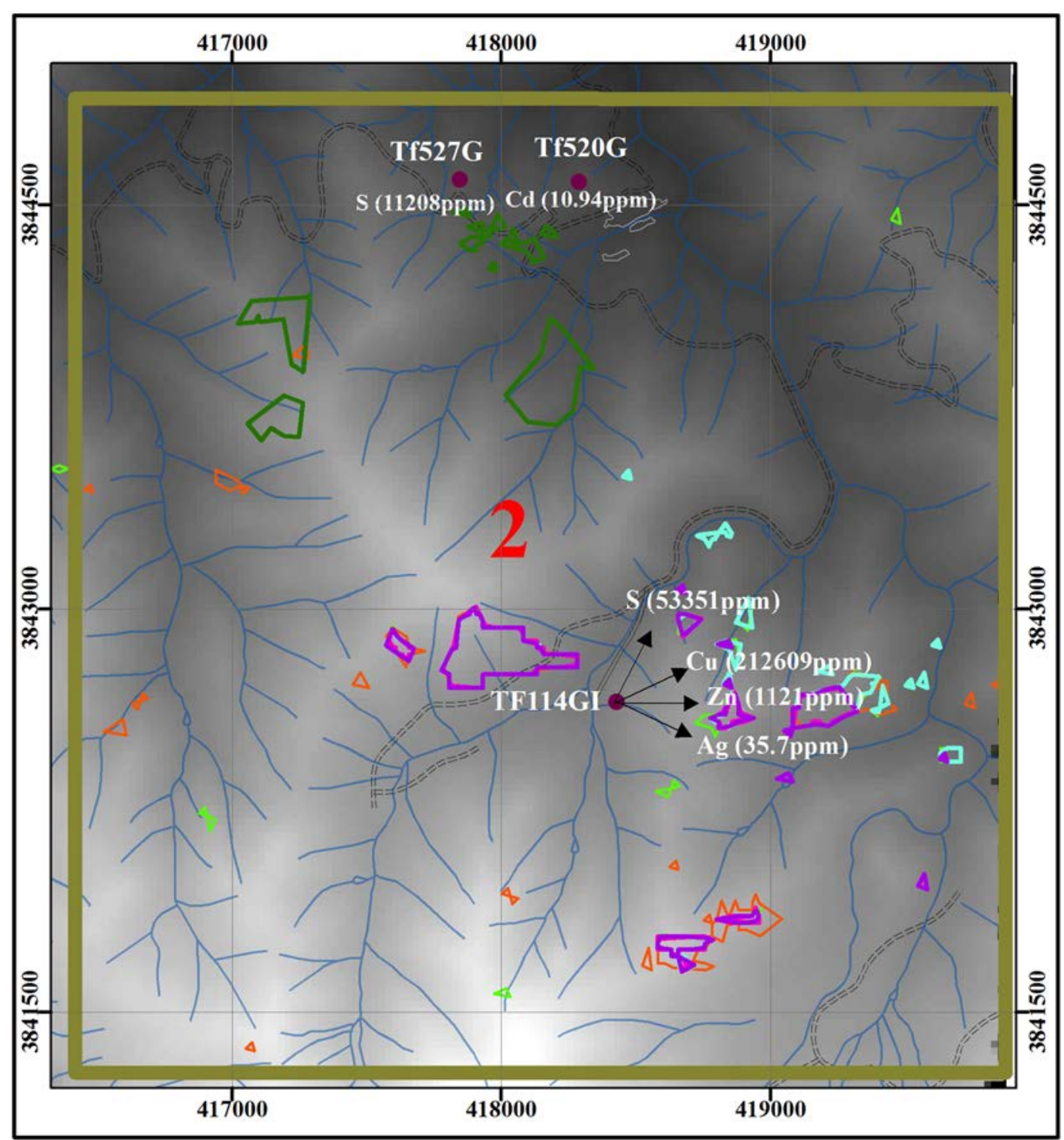

Figure 38. Second exploratory target that have high rate of concentration of mineralization such as $\mathrm{Cu}, \mathrm{Zn}$, $\mathrm{Mo}$, and $\mathrm{Au}, \mathrm{Ag}, \mathrm{Hg}, \mathrm{Sb}$, and $\mathrm{Fe}$.

Gold-Silver, epithermal veins (intermediate to low Sulfidation of Au and Ag), Epithermal with high sulfidation $(\mathrm{Au}, \mathrm{Ag}, \mathrm{Cu}, \mathrm{As})$.

\section{References}

[1] Darvishzadeh, A. (2003) Geology of Iran. 5th Edition, Amirkabir Publication, Tehran.

[2] Aghanabati, S.A. (2006) Geological of Iran. Geological Survey of Iran Publication, Tehran, p. 18.

[3] Emami, M.H. (1991) Description of the Geological Map of 1:250,000 Qom with Report. Geological Survey of Iran, Tehran, No. E6.

[4] Sepahi, A.A. and Malvandi, F. (2008) Petrology of the Bouein Zahra-Naein Plutonic Complexes, Urumieh-Dokhtar Belt, Iran: With Special Reference to Granitoids of the Saveh Plutonic Complex. Neues Jahrbuchfür MineralogieAbhandlungen. Journal of Mineralogy and Geochemistry, 185, 99-115. http://dx.doi.org/10.1127/0077-7757/2008/0104

[5] Mohajjel, M. and Sahandi, M.R. (1999) Tectonic Evolution of Sanandaj-Sirjan Zone at Northeastern Part of Iran and Introduction of New Subzones at It, Geoscience-Scientific Quarterly Journal, 31-32. 
http://gs-journal.ir/fa/journal/ChapterView/0/95/100/4346/.html

[6] Baranpurian, N., Emami., M.H., VossoughiAbedini, M. and Dabiri., R. (2014) Mineral Chemistry and Thermobarometry of the Upper Eocene Volcanic Rocks in NE Tafresh, Iran. Open Journal of Geology, 4, 612-621. http://dx.doi.org/10.4236/ojg.2014.412045

[7] Cox, K.G., Bell, J.D. and Pankhurst, R.J. (1979) The Interpretation of Igneous Rocks. George, Allen and Unwin, London.

[8] Le Bas, M.J., Le Maitre, R.W., Streckeisen, A. and Zanettin, B. (1986) A Chemical Classification of Volcanic Rocks Based on the Total Alkali-Silica Diagram. Journal of Petrology, 27, 745-750. http://dx.doi.org/10.1093/petrology/27.3.745

[9] Irvine, T.N. and Baragar, W.R. (1971) A Guide to the Chemical Classification of the Common Igneous Rocks. Canadian Journal of Earth Sciences, 8, 523-548. http://dx.doi.org/10.1139/e71-055

[10] Morovat Azad, F. (2014) Petrography, Geochemical, and Tectonic Environment of Lower Quaternary Volcanic Rocks (Eastern North of Sarab and Eastern Azarbayejan), Geochemical Journal, Article 2, Number 3, 199-189. http://geochem.iranjournals.ir/article_13304_1719.html

[11] Pearce, J.A. (1982) Trace element characteristics of lavas from destructive plate boundaries. In: Thorpe, R.S. (Editor), Andesites. Unwin Hyman, London, pp. 525-548.

[12] Mukhopadhyay, B. Saha, A. and Hazra, N. (2003) Knowledge Driven GIS Modelling Techniques for Copper Prospectivity Mapping in Singhbhum Copper Belt-A Retrospection. https://www.researchgate.net/publication/237759254

[13] Kazemi Mehrnia, A., et al. (2014) Report of Geological Map of Tafresh Sheet Scale 1:25000 (6059 III NW). Geological Survey of Iran, Tehran.

[14] Gill, J.B. (1981). Orogenic Andesites and Plate Tectonics. Springer, Berlin. http://link.springer.com/book/10.1007\%2F978-3-642-68012-0 http://dx.doi.org/10.1007/978-3-642-68012-0

[15] Shahhosseini, A. (2010) Study of economic geology of Tafresh 1:25000 Sheet. M.S. Thesis, Azad University North of Tehran Branch, Iran.

[16] AlviNaeeni, M.R., et al. (2002) Report of Geochemical Exploration Report of Tafresh Sheet Scale 1:100,000. Geological Survey of Iran, Tehran, $158 \mathrm{p}$.

[17] Sun, S.S. and McDonough, W.F. (1989) Chemical and Isotopic Systematics of Oceanic Basalts: Implications for Mmantle Composition and Processes. In: Sauders, A.D. and Norry, M.J., Eds., Magmatism in the Ocean Basins, Geological Society London Special Publications, 313-345. https://www.researchgate.net/publication/231575101 http://dx.doi.org/10.1144/gsl.sp.1989.042.01.19

\section{Submit or recommend next manuscript to SCIRP and we will provide best service for you:}

Accepting pre-submission inquiries through Email, Facebook, Linkedin, Twitter, etc

A wide selection of journals (inclusive of 9 subjects, more than 200 journals)

Providing a 24-hour high-quality service

User-friendly online submission system

Fair and swift peer-review system

Efficient typesetting and proofreading procedure

Display of the result of downloads and visits, as well as the number of cited articles

Maximum dissemination of your research work

Submit your manuscript at: http://papersubmission.scirp.org/ 